\title{
Developing a Hybrid Approach Based on Analytical and Metaheuristic Optimization Algorithms for the Optimization of Renewable DG Allocation Considering Various Types of Loads
}

\author{
Amal A. Mohamed ${ }^{1}$, Salah Kamel ${ }^{1} \mathbb{D}$, Ali Selim ${ }^{1}\left(\mathbb{D}\right.$, Tahir Khurshaid ${ }^{2, *} \mathbb{C}$ and Sang-Bong Rhee ${ }^{2, *}$ \\ 1 Department of Electrical Engineering, Faculty of Engineering, Aswan University, Aswan 81542, Egypt; \\ amal.amin13@yahoo.com (A.A.M.); skamel@aswu.edu.eg (S.K.); ali.selim@aswu.edu.eg (A.S.) \\ 2 Department of Electrical Engineering, Yeungnam University, Gyeongsan 38541, Korea \\ * Correspondence: tahir@ynu.ac.kr (T.K.); rrsd@yu.ac.kr (S.-B.R.)
}

\section{check for} updates

Citation: Mohamed, A.A.; Kamel, S.; Selim, A.; Khurshaid, T.; Rhee, S.-B. Developing a Hybrid Approach Based on Analytical and

Metaheuristic Optimization

Algorithms for the Optimization of Renewable DG Allocation Considering Various Types of Loads. Sustainability 2021, 13, 4447. https:// doi.org/10.3390/su13084447

Academic Editor: Cristina Rodriguez

Received: 21 February 2021

Accepted: 26 March 2021

Published: 16 April 2021

Publisher's Note: MDPI stays neutral with regard to jurisdictional claims in published maps and institutional affiliations.

Copyright: (c) 2021 by the authors. Licensee MDPI, Basel, Switzerland. This article is an open access article distributed under the terms and conditions of the Creative Commons Attribution (CC BY) license (https:// creativecommons.org/licenses/by/ $4.0 /)$.

\begin{abstract}
The optimal location of renewable distributed generations (DGs) into a radial distribution system (RDS) has attracted major concerns from power system researchers in the present years. The main target of DG integration is to improve the overall system performance by minimizing power losses and improving the voltage profile. Hence, this paper proposed a hybrid approach between an analytical and metaheuristic optimization technique for the optimal allocation of DG in RDS, considering different types of load. A simple analytical technique was developed in order to determine the sizes of different and multiple DGs, and a new efficient metaheuristic technique known as the Salp Swarm Algorithm (SSA) was suggested in order to choose the best buses in the system, proportionate to the sizes determined by the analytical technique, in order to obtain the minimum losses and the best voltage profile. To verify the power of the proposed hybrid technique on the incorporation of the DGs in RDS, it was applied to different types of static loads; constant power $(\mathrm{CP})$, constant impedance $(\mathrm{CZ})$, and constant current $(\mathrm{CI})$. The performance of the proposed algorithm was validated using two standards RDSs-IEEE 33-bus and IEEE 69-bus systems-and was compared with other optimization techniques.
\end{abstract}

Keywords: radial distribution networks; optimal allocation; different types of DGs; hybrid technique; analytical technique; SSA; static load; voltage stability; power loss

\section{Introduction}

The electric power distribution network is the part which connects the high voltage (HV) electric power transmission network to low voltage (LV) consumers, which is considered the substantial part of the electric power network because the power delivered from the electric power to the loads is assured by operative and reliable distribution networks. The electric power system is sectioned into three parts: generation, transmission, and the distribution network. The last part is the distribution network, which is used to link between the consumers and transmission. The electric power system suffers from two important factors: a low voltage profile and a high percentage of power losses. However, $70 \%$ of the power losses are caused at the distribution level (primary and secondary), and the remaining $30 \%$ are caused by the transmission system [1]. Hence, the distribution networks attract the main attention of the researchers.

Exiting grids are mostly characterized by centralized bulk power generation far from load centers, requiring long, costly, and lossy transmission lines for power delivery.

By incorporating distribution generation (DG) units in the radial distribution system (RDS) at appropriate places, the losses can reach the minimum value. DG is known as electricity generation by specific capacity generators associated with the electric distribution system or close to the loads. 
In smart networks, there is intense interest in the distribution systems to increase the penetration levels of renewable energy sources that are incorporated close to the point-ofuse, which achieve lower losses in energy delivery, and this makes the transactions of the power in the lines of the distribution system bidirectional [2].

Research has demonstrated that the incorporation of DG sources in the electric power distribution networks could create various benefits; some of them are:

- Improved voltages of all busses.

- Decreased power losses.

- Improved security of critical buses.

- Network reinforcement.

- The reduction of the congestion of the distribution system.

- The reduction of operation costs.

- The improvement of system reliability

It is very important to incorporate an auxiliary power system beside the main generation in order to supply the loads with sufficient energy. Hence, the electrical network must achieve reliability, which is defined as the probability of this network to perform its intended function for a specific time [3].

In order to achieve these objectives, it is necessary to specify the optimal sizes and location of DG units in distribution systems; otherwise, it could lead to reverse actions, such as the increase in active power losses and a poor voltage profile.

There are multiple types of DGs, which can be discussed as follows:

- Type I: injects only active power, with a unity power factor.

- Type II: injects only reactive power, with zero power factor.

- Type III: injects active and reactive power.

- $\quad$ Type IV: injects active power and consumes reactive power.

Different techniques have been obtained in order to solve the optimization problems: analytical optimization techniques which based on the mathematical model (such as $[4,5])$ and metaheuristic techniques such as the Ant lion optimization algorithm [6], Hybrid particle swarm optimization, and the Genetic algorithm (GA-PSO) based on active power losses [7,8]; the Artificial Bee Colony Algorithm (ABC) [9]; the Modified TeachingLearning-Based Optimization algorithm (MTLBO) [10]; and the Harmony Search Algorithm (HSA) [11]. In [12,13], the researchers used a hybrid evolutionary algorithm to specify the optimal DG placement; the improvement of the voltage profile and voltage stability were the main objectives of the researchers in $[14,15]$. There are also the Whale Optimization Algorithm (WOA) [16] and the Intersect Mutation Differential Evolution optimizer (IMDE) [17].

The loads of the electric distribution system are permanently changing due to consumer demand variations. In industrial areas, the electric power distribution network is susceptible to voltage collapse due to grievous loading conditions.

In load flow studies, it is acceptable to symbolize the composite load properties, as signified from the power given points. In the transmission networks, because of the voltage regulation, the load can be represented by using a constant power model, while in the distribution networks, the voltage is changed along the network lines because most of the buses are not voltage controlled. As such, the properties of the loads in the distribution network analysis are very important and serious.

Distribution power flow studies have been extremely influenced by load modeling. Furthermore, the load characteristics have a noticeable influence on power flow solutions and convergence ability [18].

There are two important types of load: static and dynamic loads. The dynamic loads are not signifying in power flow studies, while static load modeling expresses the active and reactive power as a function of the voltage magnitude of each bus, so it is appropriate for power flow studies, which are in turn categorized into different types of loads, as follows: constant power $(\mathrm{CP})$, constant current $(\mathrm{CI})$, and constant impedance $(\mathrm{CZ})$. 
Multiple papers have studied the effect of the DG units in RDS by considering the static load model $[19,20]$. In order to check the performance of the hybrid technique in power loss reduction and voltage improvement, it is applied to the three types of static loads.

In this paper, a hybrid analytical and metaheuristic technique is proposed in order to calculate the optimal allocation and sizing of multiple types of DGs with different types of load; the analytical technique was proposed to specify the proper size, while the Salp Swarm Algorithm (SSA) was chosen to specify best locations.

SSA is a new efficient optimization algorithm introduced by Mirjalil in 2017 [21]. The behavior of salps in a swarm for foraging or traveling across oceans is the main inspiration of this technique. Salps are a kind of Salpidae family that have a transparent barrel-shaped body; their tissues are highly similar to a jellyfish's structure. The main reason for this behavior of salps in swarms is unclear as yet, but some of the researchers believe that the swarming is performed in order to achieve the best movement using rapid coordinated alterations and foraging.

The SSA technique is simple and uncomplicated to implement, and includes one controlling parameter C_1; the acclimated mechanism of this algorithm allows it to alert solutions, and ultimately finds an exact estimation of the optimal solutions. The SSA gives strongly satisfying results when it is integrated with other techniques; it is also characterized by its speed in convergence, and is suitable for different optimization problems, while the GA is easy to understand, and deals with multi objective optimization, but one of its important disadvantages is being time consuming and computationally expensive. As such, due to these advantages, SSA is an efficient and excellent technique comparable with recent techniques; nevertheless, this cannot be ensured for all optimization problems. Additionally, the SSA has been used to solve single-objective functions in various optimization areas; the Chaotic Salp Swarm Algorithm (CSSA) is a new optimization technique which was introduced by Sayed et al. [22]. In addition, SSA has been utilized in electrical power engineering problems; in [23], El-Fergany proposed a technique to define the parameters of the polarization curves of polymer exchange membrane fuel cells (PEMFC), which are based on SSA, and in [24], the authors presented a modification and application of SSA called the enhanced salp swarm algorithm (ESSA); in [25], the SSA was employed to solve optimal power flow (OPF) problems.

The rest of the paper is sectioned as follows: the problem formulation, including the load modeling, forward/backward load flow algorithm, objective function, and operational constraints are illustrated in Section 2; the SSA is presented in Section 3; Section 4 illustrates the analytical technique; Section 5 presents the simulation results; finally, the conclusion of the paper is illustrated in Section 6.

\section{Problem Formulation}

\subsection{Load Modelling}

In this paper, three types of static loads are studied, as follows:

1. Constant impedance (CZ): the power is proportional to the square of the voltage value.

2. Constant current $(\mathrm{CI})$ : the power is proportional to the voltage value.

3. Constant power $(\mathrm{CP})$ : the power does not change with the voltage variation.

In this article, the exponential form is used to define the static load as follows:

$$
\begin{aligned}
& \mathrm{P}_{\mathrm{A}}=\mathrm{P}_{0_{\mathrm{A}}} * \mathrm{~V}_{\mathrm{A}}{ }^{\sigma} \\
& \mathrm{Q}_{\mathrm{A}}=\mathrm{Q}_{0_{\mathrm{A}}} * \mathrm{~V}_{\mathrm{A}}{ }^{\sigma}
\end{aligned}
$$

where $P_{A}$ and $Q_{A}$ are the active and reactive power at bus $A, V$ is the voltage magnitude at bus $\mathrm{A}, \sigma=0$ at constant power $(\mathrm{CP}), \sigma=1$ at constant current $(\mathrm{CI})$, and $\sigma=2$ at constant impedance $(\mathrm{CZ})$. 


\subsection{Forward-Backward Power Flow Algorithm}

RDSs have some special properties, such as a radial structure, a high $\mathrm{R} / \mathrm{X}$ ratio, and unbalanced loads. Due to the previous features, Gauss-Seidel (GS), Newton Raphson (NR), and the fast decoupled method are inefficient in radial distribution system analysis. Hence, the forward-backward load flow is a modern technique which is used in this paper to solve the load flow in RDS, which is divided into two processes: forward sweep and backward sweep. The voltage in the forward sweep is calculated from sending to the end of the feeder, while the power in the backward sweep is calculated from the end of the feeder to the source. Figure 1 illustrates two bus RDS; the active power $P_{S}$ and the reactive power $\mathrm{Q}_{\mathrm{S}}$ that flow from bus $\mathrm{S}$ to $\mathrm{T}$ can be calculated from backward sweep as follows.

$$
\begin{gathered}
P_{S}=P_{T}+P_{L, T}+R\left(\frac{\left(P_{T}+P_{L, T}\right)^{2}+\left(Q_{T}+Q_{L, T}\right)^{2}}{\left|V_{T}\right|^{2}}\right) . \\
Q_{S}=Q_{T}+Q_{L, T}+X\left(\frac{\left(P_{T}+P_{L, T}\right)^{2}+\left(Q_{T}+Q_{L, T}\right)^{2}}{\left|V_{T}\right|^{2}}\right)
\end{gathered}
$$

and the voltage of each bus can be determined in the forward sweep as:

$$
\mathrm{V}_{\mathrm{T}}^{2}=\left(\mathrm{V}_{\mathrm{S}}^{2}-2\left(\mathrm{P}_{\mathrm{S}} \mathrm{R}+\mathrm{Q}_{\mathrm{S}} \mathrm{X}\right)+\left(\mathrm{R}^{2}+\mathrm{X}^{2}\right) \frac{\left(\mathrm{P}_{\mathrm{S}}^{2}+\mathrm{Q}_{\mathrm{S}}^{2}\right)}{\mathrm{V}_{\mathrm{S}}^{2}}\right)
$$

therefore, the active power loss in the branch from $S$ to $\mathrm{T}$ can be determined as:

$$
\mathrm{P}_{\operatorname{loss}(\mathrm{S}, \mathrm{T})}=\mathrm{R}_{\mathrm{S}, \mathrm{T}}\left(\frac{\mathrm{P}_{\mathrm{S}}^{2}+\mathrm{j}_{\mathrm{S}}^{2}}{\left|\mathrm{~V}_{\mathrm{S}}\right|^{2}}\right)
$$

and the reactive power loss in the branch from $\mathrm{S}$ to $\mathrm{T}$ can be determined as:

$$
\mathrm{Q}_{\operatorname{loss}(\mathrm{S}, \mathrm{T})}=\mathrm{x}_{\mathrm{S}, \mathrm{T}}\left(\frac{\mathrm{P}_{\mathrm{S}}^{2}+\mathrm{jQ}_{\mathrm{S}}^{2}}{\left|\mathrm{~V}_{\mathrm{S}}\right|^{2}}\right)
$$

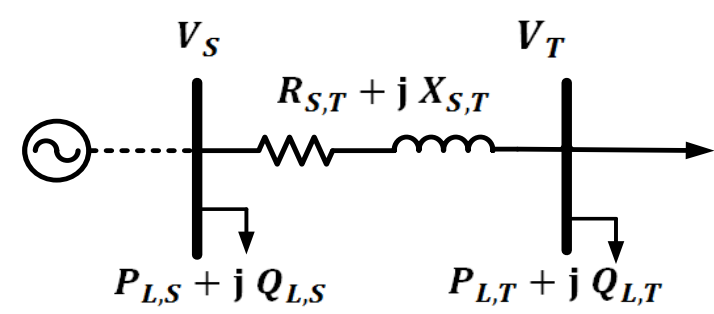

Figure 1. Two bus radial distribution network.

Hence, the total active and reactive power losses in RDS can be estimated as:

$$
\begin{gathered}
\mathrm{TPL}=\sum_{\mathrm{s}, \mathrm{t}=1}^{\mathrm{Br}}\left(\mathrm{P}_{\text {Loss }}(\mathrm{S}, \mathrm{T})\right) \\
\mathrm{TQL}=\sum_{\mathrm{s}, \mathrm{t}=1}^{\mathrm{Br}}\left(\mathrm{Q}_{\text {Loss }}(\mathrm{S}, \mathrm{T})\right)
\end{gathered}
$$




\subsection{Objective Function}

In general, incorporating DGs into RDS reduces the power losses by reducing the amount of current flowing in the lines; also, it can improve the overall voltage profile, which in turn improves the efficiency of the network.

In the present work, the main objective function is to minimize total active power losses. Therefore, the objective function can be formulated as:

$$
\mathrm{P}_{\text {Loss }}=\sum_{\mathrm{S}=1}^{\mathrm{No}} \sum_{\mathrm{T}=1}^{\mathrm{No}} \alpha_{\mathrm{ST}}\left(\mathrm{P}_{\mathrm{S}} \mathrm{P}_{\mathrm{T}}+\mathrm{Q}_{\mathrm{S}} \mathrm{Q}_{\mathrm{T}}\right)+\beta_{\mathrm{ST}}\left(\mathrm{Q}_{\mathrm{S}} \mathrm{P}_{\mathrm{T}}-\mathrm{P}_{\mathrm{S}} \mathrm{Q}_{\mathrm{T}}\right)
$$

$\mathrm{P}_{\mathrm{S}}$ and $\mathrm{P}_{\mathrm{T}}$ are the active power at bus $\mathrm{S}$ and $\mathrm{T}$, respectively

$\mathrm{Q}_{\mathrm{S}}$ and $\mathrm{Q}_{\mathrm{T}}$ are the reactive power at bus $\mathrm{S}$ and $\mathrm{T}$, respectively.

\subsection{Operation Constraints}

2.4.1. Equality Constraints

$$
\begin{aligned}
\mathrm{P}_{\text {Slack }}+\sum_{\mathrm{A}}^{\mathrm{No}} \mathrm{P}_{\mathrm{DG}(\mathrm{A})} & =\sum_{\mathrm{A}}^{\text {No }} \mathrm{P}_{\mathrm{Load}(\mathrm{A})}+\sum_{\mathrm{B}}^{\mathrm{Br}} \mathrm{P}_{\mathrm{Loss}(\mathrm{B})} \\
\mathrm{Q}_{\text {Slack }}+\sum_{\mathrm{A}}^{\text {No }} \mathrm{Q}_{\mathrm{DG}(\mathrm{A})} & =\sum_{\mathrm{A}}^{\text {No }} \mathrm{Q}_{\mathrm{Load}(\mathrm{A})}+\sum_{\mathrm{B}}^{\mathrm{Br}} \mathrm{Q}_{\mathrm{Loss}(\mathrm{B})}
\end{aligned}
$$

$P_{\text {Slack, }} Q_{\text {Slack }}$ are the active and reactive power of the slack bus, respectively.

No: number of buses; Br: number of branches; $\mathrm{P}_{\text {Loss }}$ : active power loss.

\subsubsection{Inequality Constraints}

The voltage at each bus must be between 0.90 and 1.05 .

$$
\mathrm{V}_{\min } \leq \mathrm{V}_{\mathrm{A}} \leq \mathrm{V}_{\max }
$$

The total reactive power injected by the DG is less than the total reactive power of loads.

$$
\sum \mathrm{Q}_{\mathrm{DG}} \leq \sum_{\mathrm{A}}^{\mathrm{No}} \mathrm{Q}_{\text {Load(A) }}
$$

The total active power injected by the DG is less than the total active power loads.

$$
\sum \mathrm{P}_{\mathrm{DG}} \leq \sum_{\mathrm{A}}^{\mathrm{NO}} \mathrm{P}_{\mathrm{Load}(\mathrm{A})}
$$

\section{Salp Swarm Algorithm (SSA)}

The SSA is a type of Salp family, and it is similar to a jellyfish's body. The SSA inhabits oceans, and they derive their movement from water power to look for food, which adjust as swarms, and are known as salp chains.

The SSA typifies the solutions of the given problems by the position number of the salps, which are represented by (salp chain) in the dimension of ( $\mathrm{n} \times \operatorname{dim})$, where $n$ is the search agent and dim is the proposed variable. The salp chain is categorized into two groups; the first one is the leader (in the front of the chain) and the second is the follower (all other salps in the swarm), as shown in Figure 2. 


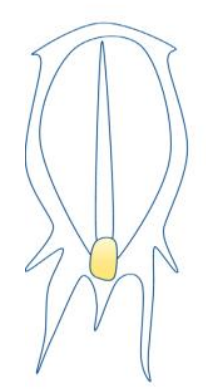

(a)

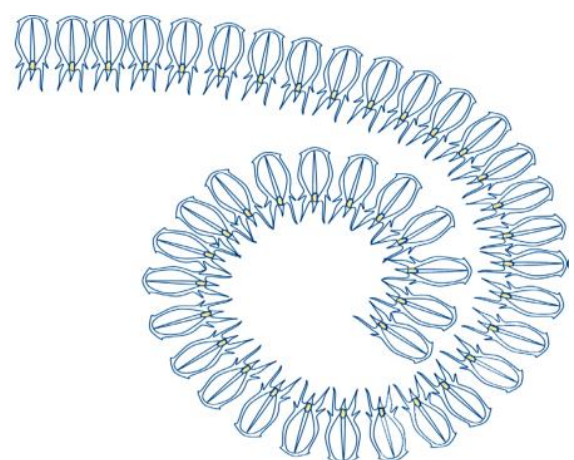

(b)

Figure 2. (a) Individual salp; (b) swarm of salps (salps chain) [19].

The optimal solution (the preferable salp) is considered as the swarm's main target (food), which is followed up by the follower's group. When the leader updates its position according to the best food, it explores the search space carefully to obtain the best solution, and the follower follows the leader.

The leader of the chain updates its place concerning a food source, which is formulated as:

$$
A_{j}^{1}= \begin{cases}H_{j}+c_{1}\left(\left(U_{j}-L_{j}\right) c_{2}+L_{j}\right) & c_{3} \geq 0 \\ H_{j}-c_{1}\left(\left(U_{j}-L_{j}\right) c_{2}+L_{j}\right) & c_{3}<0\end{cases}
$$

$A_{j}{ }^{1}$ is the leader position, $H_{j}$ is the position of the food source.

$\mathrm{L}_{\mathrm{j}}$ and $\mathrm{U}_{\mathrm{j}}$ represent the lower and upper boundaries, respectively. $\mathrm{c}_{2}$ and $\mathrm{c}_{3}$ are random numbers, where

$$
c_{1}=2 e^{-\left(\frac{4 x}{x}\right)^{2}}
$$

$\mathrm{x}$ is the current iteration and $X$ is the maximum number of iterations. By Newton's law of motion, the follower salps update their position:

$$
\mathrm{A}_{\mathrm{j}}^{\mathrm{i}}=\frac{1}{2}\left(\mathrm{aw}^{2}+\mathrm{v}_{\mathrm{o}} \mathrm{wi}\right) \geq 2
$$

where $A_{j}{ }^{i}$ is the follower salp position, $v_{o}$ is the initial speed, and $w$ is the number of the iteration.

Then, Equation (18) can be reorganized as:

$$
A_{j}^{i}=\frac{1}{2}\left(A_{j}^{i}+A_{j}^{i-1}\right)
$$

The application of SSA for the optimal placement of DGs units can be summarized in the following steps:

- Step 1: specify the input variables of the SSA, which include the search agent, the number of iterations, and the lower and upper variable.

- $\quad$ Step 2: start the population of the SSA randomly, using (20).

$$
\mathrm{A}(\mathrm{n}, \mathrm{m})=\operatorname{rand}(\mathrm{n}, 1) *(\mathrm{U}-\mathrm{L})+\mathrm{L}
$$

- Step 3: run the forward-backward load flow code and determine the fitness function.

- Step 4: calculate the best position according to the optimal fitness function.

- Step 5: update the position of the leader salp according to (16).

- Step 6: update the position of the follower salp according to (19).

- Step 7: verify the limits of the header and follower of the salp chain.

- Step 8: run the forward-backward load flow code in order to determine the fitness function for the positions which updated, then calculate the optimal position. 
- Step 9: repeat the previous steps from step 5 to step 8 until the current iteration equals a maximum number of iterations.

- Step 10: finally, find an optimal position represented by the food source and the associated fitness function.

\section{Optimal Sizes}

From Figure 1, the total active power losses $\left(P_{\text {Loss }}\right)$ in the RDS are calculated as:

$$
\begin{aligned}
& \alpha_{\mathrm{ST}}=\frac{\mathrm{R}_{\mathrm{ST}}}{\mathrm{V}_{\mathrm{S}} \mathrm{V}_{\mathrm{T}}} \cos \left(\alpha_{\mathrm{S}}-\alpha_{\mathrm{T}}\right) \\
& \beta_{\mathrm{ST}}=\frac{\mathrm{R}_{\mathrm{ST}}}{\mathrm{V}_{\mathrm{S}} \mathrm{V}_{\mathrm{T}}} \sin \left(\alpha_{\mathrm{S}}-\alpha_{\mathrm{T}}\right)
\end{aligned}
$$

$\mathrm{V}_{\mathrm{S}}$ and $\mathrm{V}_{\mathrm{T}}$ are the voltage magnitude at bus $\mathrm{S}$ and $\mathrm{T}$, respectively

$Z_{S T}=R_{S T}+j X_{S T}$, where $Z_{S T}$ bus impedance matrix.

We assume that $\mathrm{x}$ is the number of the DG which supplies only active power (Type I)

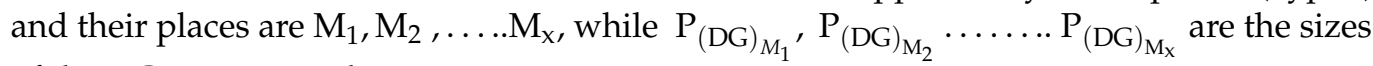
of the DGs, respectively.

Therefore, the active power from Type I can be:

$\left[\mathrm{P}_{\mathrm{M}_{1}}=\mathrm{P}_{(\mathrm{DG})_{\mathrm{M}_{1}}}-\mathrm{P}_{(\text {Load })_{\mathrm{M}_{1}}}\right], \ldots \ldots,\left[\mathrm{P}_{\mathrm{M}_{\mathrm{x}}}=\mathrm{P}_{(\mathrm{DG})_{\mathrm{M}_{\mathrm{x}}}}-\mathrm{P}_{(\text {Load })_{\mathrm{M}_{\mathrm{x}}}}\right]$. Furthermore, the number of the DGs supplying reactive power (Type II) is $y$, and their places are $\mathrm{N}_{1}, \mathrm{~N}_{2}, \ldots \ldots \mathrm{N}_{\mathrm{y}}$, while $Q_{(D G)_{N_{1}}}, Q_{(D G)_{N_{2}}} \ldots \ldots . . Q_{(D G)_{N_{y}}}$ are the sizes of the DGs, respectively.

The reactive power from Type II can be written as: $\left[\mathrm{Q}_{\mathrm{N}_{1}}=\mathrm{Q}_{(\mathrm{DG})_{\mathrm{N}_{1}}}-\mathrm{Q}_{(\mathrm{Load})_{\mathrm{N}_{1}}}\right] \ldots \ldots$, $\left[\mathrm{Q}_{\mathrm{N}_{\mathrm{y}}}=\mathrm{Q}_{(\mathrm{DG})_{\mathrm{Ny}}}-\mathrm{Q}_{(\mathrm{Load})_{\mathrm{Ny}}}\right]$.

The minimum power losses can be obtained if the first derivative of the power losses with respect to the power supplied from the DGs becomes zero; therefore, it can be formed as:

$$
\frac{\partial \mathrm{P}_{\text {Loss }}}{\partial \mathrm{P}_{\mathrm{M}_{1}}}=2 \alpha_{\mathrm{M}_{1} \mathrm{M}_{1}} \mathrm{P}_{\mathrm{M}_{1}}+2 \sum_{\substack{\mathrm{T}=1 \\ \mathrm{~T} \neq \mathrm{M}_{1}}}^{\text {No }}\left(\alpha_{\mathrm{M}_{1} \mathrm{~T}} \mathrm{P}_{\mathrm{T}}-\beta_{\mathrm{M}_{1} \mathrm{~T}} \mathrm{Q}_{\mathrm{T}}\right)
$$

or

$$
\begin{aligned}
& \alpha_{\mathrm{M}_{1} \mathrm{M}_{1}} \mathrm{P}_{\mathrm{M}_{1}}+\alpha_{\mathrm{M}_{1} \mathrm{M}_{2}} \mathrm{P}_{\mathrm{M}_{2}}+\ldots+\alpha_{\mathrm{M}_{1} \mathrm{M}_{\mathrm{x}}} \mathrm{P}_{\mathrm{M}_{\mathrm{x}}}-\beta_{\mathrm{M}_{1} \mathrm{~N}_{1}} \mathrm{Q}_{\mathrm{N}_{1}}-\beta_{\mathrm{M}_{1} \mathrm{~N}_{2}} \mathrm{Q}_{\mathrm{N}_{2}}-\ldots \\
& -\beta_{\mathrm{M}_{1} \mathrm{~N}_{\mathrm{y}}} \mathrm{Q}_{\mathrm{N}_{\mathrm{y}}}=-\quad \sum_{\mathrm{T}=1}^{\mathrm{No}} \quad\left(\alpha_{\mathrm{M}_{1} \mathrm{~T}} \mathrm{P}_{\mathrm{T}}-\beta_{\mathrm{M}_{1} \mathrm{~T}} \mathrm{Q}_{\mathrm{T}}\right) \\
& \mathrm{T} \neq \mathrm{M}_{1}, \mathrm{M}_{2}, \ldots, \quad \mathrm{M}_{\mathrm{x}} \\
& \mathrm{T} \neq \mathrm{N}_{1}, \mathrm{~N}_{2}, \ldots . ., \mathrm{N}_{\mathrm{y}}
\end{aligned}
$$

The derivative of the active power loss according to active power injection $P_{M_{x}}$ can be formulated as:

$$
\frac{\partial \mathrm{P}_{\text {Loss }}}{\partial \mathrm{P}_{\mathrm{M}_{\mathrm{x}}}}=2 \alpha_{\mathrm{M}_{\mathrm{x}} \mathrm{M}_{\mathrm{x}}} \mathrm{P}_{\mathrm{M}_{\mathrm{x}}}+2 \sum_{\substack{\mathrm{T}=1 \\ \mathrm{~T} \neq \mathrm{M}_{\mathrm{x}}}}^{\mathrm{No}}\left(\alpha_{\mathrm{M}_{\mathrm{x}} \mathrm{T}} \mathrm{P}_{\mathrm{T}}-\beta_{\mathrm{M}_{\mathrm{x}} \mathrm{T}} \mathrm{Q}_{\mathrm{T}}\right)
$$

or

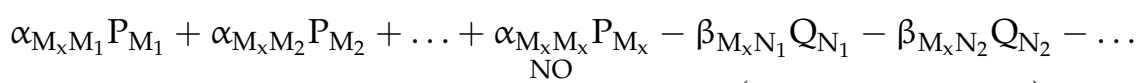

$$
\begin{aligned}
& -\beta_{\mathrm{M}_{\mathrm{x}} \mathrm{N}_{\mathrm{y}}} \mathrm{Q}_{\mathrm{N}_{\mathrm{y}}}=-\quad \sum_{\mathrm{T}=1}^{\mathrm{NO}} \quad\left(\alpha_{\mathrm{M}_{\mathrm{x}} \mathrm{T}} \mathrm{P}_{\mathrm{T}}-\beta_{\mathrm{M}_{\mathrm{x}} \mathrm{T}} \mathrm{Q}_{\mathrm{T}}\right) \\
& \mathrm{T} \neq \mathrm{M}_{1}, \mathrm{M}_{2}, \ldots, \quad \mathrm{M}_{\mathrm{x}} \\
& \mathrm{T} \neq \mathrm{N}_{1}, \mathrm{~N}_{2}, \ldots . ., \mathrm{N}_{\mathrm{y}}
\end{aligned}
$$


Furthermore, the derivative of the active power losses regarding to the reactive power injection $Q_{N_{1}}$ can be formulated as:

$$
\frac{\partial \mathrm{P}_{\text {Loss }}}{\partial \mathrm{Q}_{\mathrm{N}_{1}}}=2 \alpha_{\mathrm{N}_{1} \mathrm{~N}_{1}} \mathrm{Q}_{\mathrm{N}_{1}}+2 \sum_{\substack{\mathrm{T}=1 \\ \mathrm{~T} \neq \mathrm{N}_{1}}}^{\mathrm{No}}\left(\alpha_{\mathrm{N}_{1} \mathrm{~T}} \mathrm{P}_{\mathrm{T}}-\beta_{\mathrm{N}_{1} \mathrm{~T}} \mathrm{Q}_{\mathrm{T}}\right)
$$

or

$$
\begin{aligned}
& \beta_{\mathrm{N}_{1} \mathrm{M}_{1}} \mathrm{P}_{\mathrm{M}_{1}}+\beta_{\mathrm{N}_{1} \mathrm{M}_{2}} \mathrm{P}_{\mathrm{M}_{2}}+\ldots+\beta_{\mathrm{N}_{1} \mathrm{M}_{\mathrm{x}}} \mathrm{P}_{\mathrm{M}_{\mathrm{x}}}-\alpha_{\mathrm{N}_{1} \mathrm{~N}_{1}} \mathrm{Q}_{\mathrm{N}_{1}}-\alpha_{\mathrm{N}_{1} \mathrm{~N}_{2}} \mathrm{Q}_{\mathrm{N}_{2}}-\ldots \\
& -\alpha_{\mathrm{N}_{1} \mathrm{~N}_{\mathrm{my}}} \mathrm{Q}_{\mathrm{N}_{\mathrm{y}}}=-\quad \sum_{\mathrm{T}=1}^{\mathrm{No}} \quad\left(\alpha_{\mathrm{N}_{1} \mathrm{~T}} \mathrm{Q}_{\mathrm{T}}+\beta_{\mathrm{N}_{1} \mathrm{~T}} \mathrm{P}_{\mathrm{T}}\right) \\
& \mathrm{T} \neq \mathrm{M}_{1}, \mathrm{M}_{2}, \ldots, \quad \mathrm{M}_{\mathrm{x}} \\
& \mathrm{T} \neq \mathrm{N}_{1}, \mathrm{~N}_{2}, \ldots . ., \mathrm{N}_{\mathrm{y}}
\end{aligned}
$$

Similarly, the derivative for $Q_{N_{y}}$ is

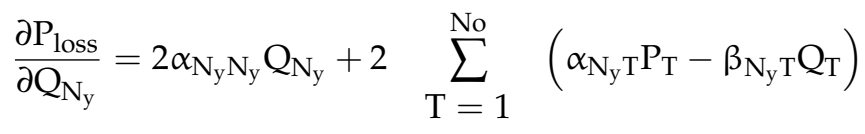

$$
\begin{aligned}
& \mathrm{T} \neq \mathrm{N}_{\mathrm{y}} \\
& \beta_{\mathrm{N}_{\mathrm{y}} \mathrm{M}_{1}} \mathrm{P}_{\mathrm{M}_{1}}+\beta_{\mathrm{N}_{\mathrm{y}} \mathrm{M}_{2}} \mathrm{P}_{\mathrm{M}_{2}}+\ldots+\beta_{\mathrm{N}_{\mathrm{y}} \mathrm{M}_{\mathrm{x}}} \mathrm{P}_{\mathrm{M}_{\mathrm{x}}}-\alpha_{\mathrm{N}_{\mathrm{y}} \mathrm{N}_{1}} \mathrm{Q}_{\mathrm{N}_{1}}-\alpha_{\mathrm{N}_{\mathrm{y}} \mathrm{N}_{2}} \mathrm{Q}_{\mathrm{N}_{2}}-\ldots
\end{aligned}
$$

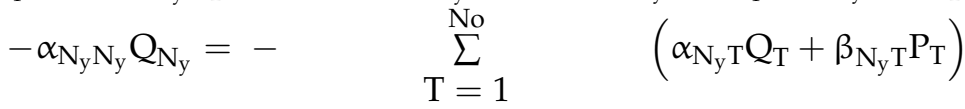

$$
\begin{aligned}
& \mathrm{T} \neq \mathrm{M}_{1}, \mathrm{M}_{2}, \ldots, \quad \mathrm{M}_{\mathrm{x}} \\
& \mathrm{T} \neq \mathrm{N}_{1}, \mathrm{~N}_{2}, \ldots . ., \mathrm{N}_{\mathrm{y}}
\end{aligned}
$$

After reorganizing the above equations, they can be rewritten as illustrate below:

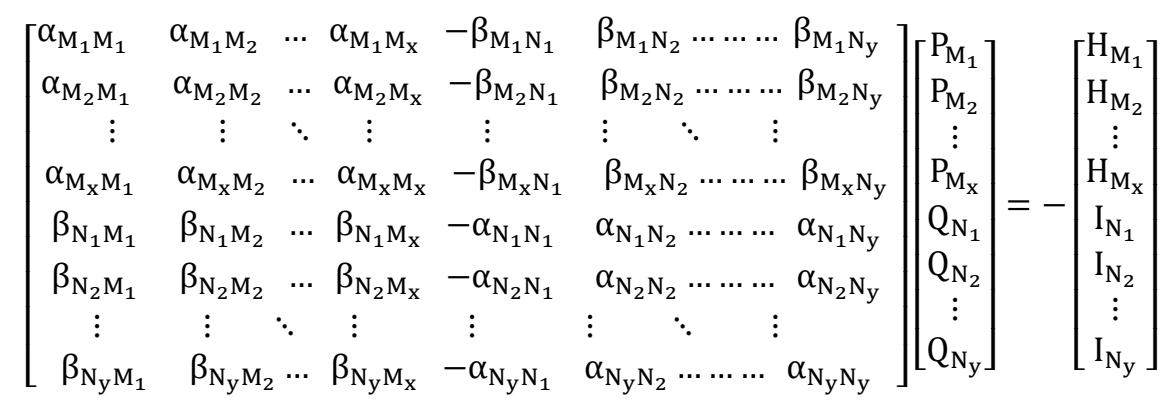

where

$$
\begin{aligned}
& \mathrm{H}_{\mathrm{M}_{\mathrm{i}}}=\quad \sum_{\mathrm{T}=1}^{\mathrm{No}} \quad\left(\alpha_{\mathrm{M}_{1} \mathrm{~T}} \mathrm{P}_{\mathrm{T}}-\beta_{\mathrm{M}_{1} \mathrm{~T}} \mathrm{Q}_{\mathrm{T}}\right), \mathrm{i}=1,2,3 \ldots \ldots \ldots \mathrm{x} \\
& \mathrm{T} \neq \mathrm{M}_{1}, \mathrm{M}_{2}, \ldots, \quad \mathrm{M}_{\mathrm{x}} \\
& \mathrm{T} \neq \mathrm{N}_{1}, \mathrm{~N}_{2}, \ldots . ., \mathrm{N}_{\mathrm{y}} \\
& \mathrm{I}_{Y_{\mathrm{i}}}=\quad \sum_{\mathrm{T}=1}^{\mathrm{No}} \quad\left(\alpha_{\mathrm{N}_{1} \mathrm{~T}} \mathrm{Q}_{\mathrm{T}}+\beta_{\mathrm{N}_{1} \mathrm{~T}} \mathrm{P}_{\mathrm{T}}\right), \mathrm{i}=1,2,3 \ldots \ldots \ldots . \mathrm{y} \\
& \mathrm{T} \neq \mathrm{M}_{1}, \mathrm{M}_{2}, \ldots, \quad \mathrm{M}_{\mathrm{x}} \\
& \mathrm{T} \neq \mathrm{N}_{1}, \mathrm{~N}_{2}, \ldots . ., \mathrm{N}_{\mathrm{y}}
\end{aligned}
$$

If we assume the matrix in (31) is equal: 


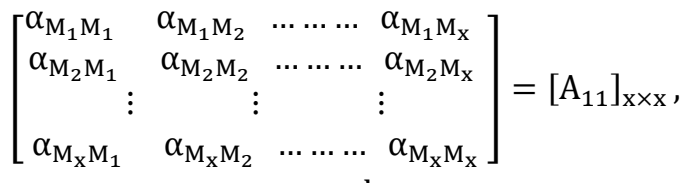

$$
\begin{aligned}
& \text { and } \\
& {\left[\begin{array}{cccc}
-\beta_{\mathrm{M}_{1} \mathrm{~N}_{1}} & \beta_{\mathrm{M}_{1} \mathrm{~N}_{2}} \ldots \ldots & \ldots & \beta_{\mathrm{M}_{1} \mathrm{~N}_{\mathrm{y}}} \\
-\beta_{\mathrm{M}_{2} \mathrm{~N}_{1}} & \beta_{\mathrm{M}_{2} \mathrm{~N}_{2}} & \ldots & \beta_{\mathrm{M}_{2} \mathrm{~N}_{\mathrm{y}}}
\end{array}\right.} \\
& \begin{array}{ccccc}
-\beta_{\mathrm{M}_{2} \mathrm{~N}_{1}} & \beta_{\mathrm{M}_{2} \mathrm{~N}_{2}} & \cdots & \beta_{\mathrm{M}_{2} \mathrm{~N}_{\mathrm{y}}} \\
\vdots & \vdots & & \vdots
\end{array}=\left[\mathrm{A}_{12}\right]_{\mathrm{x} \times \mathrm{y}} \\
& {\left[\begin{array}{cccc}
\vdots & \vdots & & \vdots \\
-\beta_{\mathrm{M}_{\mathrm{x}} \mathrm{N}_{1}} & \beta_{\mathrm{M}_{\mathrm{x}} \mathrm{N}_{2}} & \ldots & \ldots \\
\mathrm{M}_{\mathrm{X}} \mathrm{N}_{\mathrm{y}}
\end{array}\right]}
\end{aligned}
$$

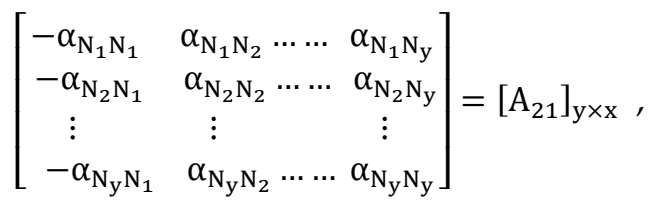

$$
\begin{aligned}
& \text { and }
\end{aligned}
$$

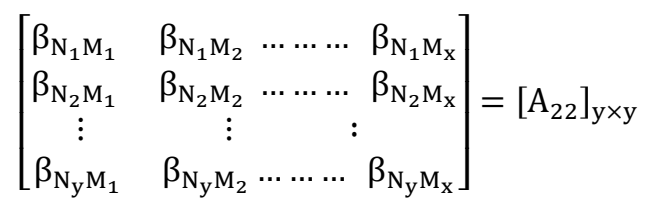

Then, after reorganization, it becomes:

$$
\left[\begin{array}{cc}
{\left[\mathrm{A}_{11}\right]_{\mathrm{x} \times \mathrm{x}}} & {\left[\mathrm{A}_{12}\right]_{x \times y}} \\
{\left[\mathrm{~A}_{21}\right]_{\mathrm{y} \times \mathrm{x}}} & {\left[\mathrm{A}_{22}\right]_{\mathrm{y} \times \mathrm{y}}}
\end{array}\right]\left[\begin{array}{c}
{\left[\mathrm{P}_{\mathrm{M}_{\mathrm{i}}}\right]_{\mathrm{x} \times 1}} \\
{\left[\mathrm{Q}_{\mathrm{N}_{\mathrm{i}}}\right]_{\mathrm{y} \times 1}}
\end{array}\right]=\left[\begin{array}{c}
{\left[\mathrm{H}_{\mathrm{M}_{\mathrm{i}}}\right]_{\mathrm{x} \times 1}} \\
{\left[\mathrm{I}_{\mathrm{N}_{\mathrm{i}}}\right]_{\mathrm{y} \times 1}}
\end{array}\right]
$$

Next

$$
\left[\begin{array}{l}
{\left[\mathrm{P}_{\mathrm{M}_{\mathrm{i}}}\right]_{\mathrm{x} \times 1}} \\
{\left[\mathrm{Q}_{\mathrm{N}_{\mathrm{i}}}\right]_{\mathrm{y} \times 1}}
\end{array}\right]=\text { inverse }\left[\begin{array}{ll}
{\left[\mathrm{A}_{11}\right]_{\mathrm{x} \times \mathrm{x}}} & {\left[\mathrm{A}_{12}\right]_{\mathrm{x} \times \mathrm{y}}} \\
{\left[\mathrm{A}_{21}\right]_{\mathrm{y} \times \mathrm{x}}} & {\left[\mathrm{A}_{22}\right]_{\mathrm{y} \times \mathrm{y}}}
\end{array}\right]\left[\begin{array}{c}
{\left[\mathrm{H}_{\mathrm{M}_{\mathrm{i}}}\right]_{\mathrm{x} \times 1}} \\
{\left[\mathrm{I}_{\mathrm{N}_{\mathrm{i}}}\right]_{\mathrm{y} \times 1}}
\end{array}\right]
$$

Then

$$
\begin{gathered}
\text { Inverse }\left[\begin{array}{ll}
{\left[\mathrm{A}_{11}\right]_{\mathrm{x} \times \mathrm{x}}} & {\left[\mathrm{A}_{12}\right]_{\mathrm{y} \times \mathrm{x}}} \\
{\left[\mathrm{A}_{21}\right]_{\mathrm{y} \times \mathrm{x}}} & {\left[\mathrm{A}_{22}\right]_{\mathrm{y} \times \mathrm{y}}}
\end{array}\right]=\left[\begin{array}{ll}
{\left[\mathrm{A}_{11}^{\prime}\right]} & {\left[\mathrm{A}^{\prime}{ }_{12}\right]} \\
{\left[\mathrm{A}^{\prime}{ }_{21}\right]} & {\left[\mathrm{A}^{\prime}{ }_{22}\right.}
\end{array}\right] \\
{\left[\mathrm{P}_{\mathrm{M}_{\mathrm{i}}}\right]_{\mathrm{x} \times 1}=\left[\mathrm{A}^{\prime}{ }_{11}\right]_{\mathrm{x} \times \mathrm{x}}\left[\mathrm{H}_{\mathrm{M}_{\mathrm{i}}}\right]_{\mathrm{x} \times 1}+\left[\mathrm{A}^{\prime}{ }_{12}\right]_{\mathrm{x} \times \mathrm{y}}\left[\mathrm{I}_{\mathrm{N}}\right]_{\mathrm{y} \times 1}} \\
{\left[\mathrm{Q}_{\mathrm{N}_{\mathrm{i}}}\right]_{\mathrm{y} \times 1}=\left[\mathrm{A}^{\prime}{ }_{21}\right]_{\mathrm{y} \times \mathrm{x}}\left[\mathrm{H}_{\mathrm{M}_{\mathrm{i}}}\right]_{\mathrm{x} \times 1}+\left[\mathrm{A}^{\prime}{ }_{22}\right]_{\mathrm{y} \times \mathrm{y}}\left[\mathrm{I}_{\mathrm{N}_{\mathrm{i}}}\right]_{\mathrm{y} \times 1}}
\end{gathered}
$$

Finally, after the installed DG at bus $S$, the active power obtained can be calculated from the following equation:

$$
\left[\mathrm{P}_{(\mathrm{DG})_{\mathrm{M}_{\mathrm{i}}}}\right]_{\mathrm{x} \times 1}=\left[\mathrm{P}_{\mathrm{M}_{\mathrm{i}}}\right]_{\mathrm{x} \times 1}+\mathrm{P}_{(\text {Load })_{\mathrm{i}}}
$$

$\mathrm{P}_{(\text {Load })_{i}}$ : active power demand at bus $M_{i}$.

The reactive power installed from type II can be determined from the following equation:

$$
\left[\mathrm{Q}_{(\mathrm{DG})_{\mathrm{N}_{\mathrm{i}}}}\right]_{\mathrm{y} \times 1}=\left[\mathrm{Q}_{\mathrm{N}_{\mathrm{i}}}\right]_{\mathrm{y} \times 1}+\mathrm{Q}_{(\text {Load })_{\mathrm{i}}}
$$

$\mathrm{Q}_{(\text {Load })}$ : reactive power demand at bus $N_{i}$.

Note that:

- $\quad$ For type I of the DG, $M_{S} \neq N_{T} \forall T$

- $\quad$ For type II of the DG, $N_{S} \neq M_{T} \forall T$

- $\quad$ For type III of the DG, $M_{S}=N_{T}$ 
The power factor of Type III (injects active and reactive power) is calculated using (41) and (42), which can be evaluated as:

$$
\mathrm{PF}=\frac{\mathrm{P}_{(\mathrm{DG})_{\mathrm{i}}}}{\sqrt{\mathrm{P}_{(\mathrm{DG})_{\mathrm{i}}}{ }^{2}+\mathrm{Q}_{(\mathrm{DG})_{\mathrm{i}}}{ }^{2}}}
$$

\section{Results and Discussion}

In the present work, two IEEE systems were chosen to check the effectiveness of the proposed technique. The IEEE 33-bus and IEEE 69-bus are shown in Figures 3 and 4; their base voltages and apparent power are $12.66 \mathrm{kV}$ and $100 \mathrm{MVA}$, respectively.

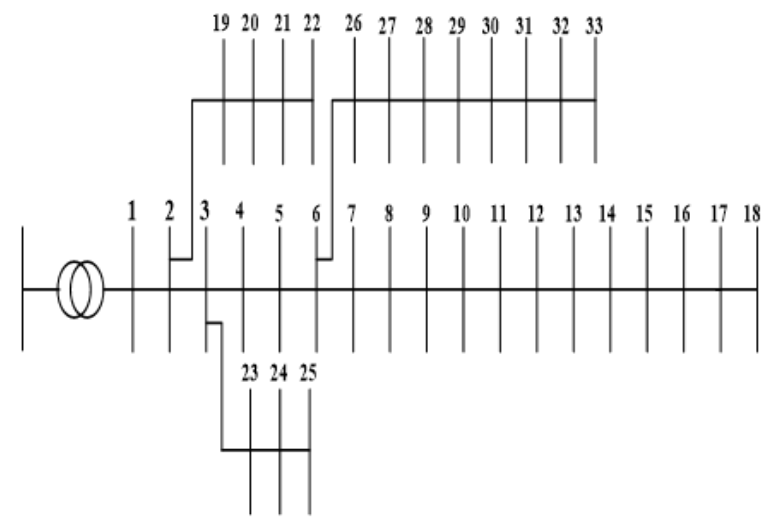

Figure 3. Single line diagram of the 33-bus system.

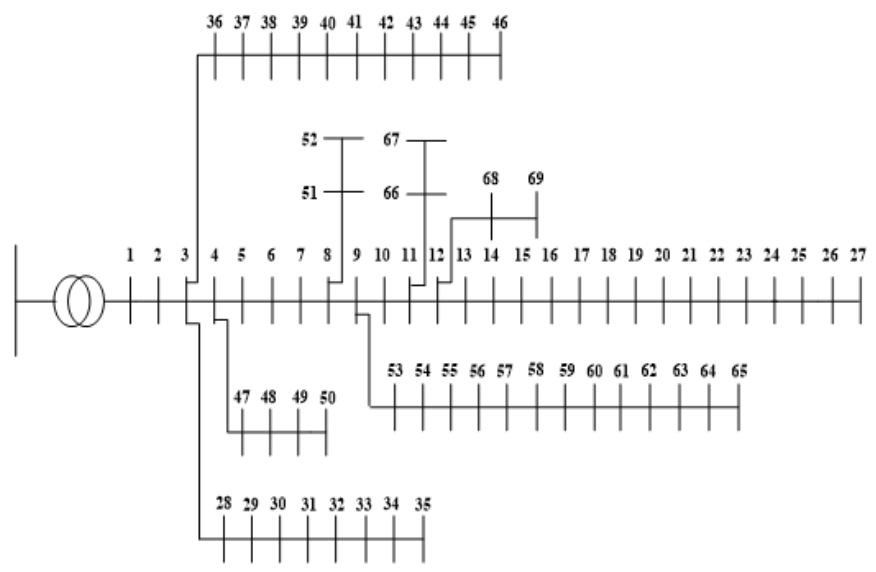

Figure 4. Single line diagram of the 69-bus system.

In order to obtain the optimal size and location of the DGs, the SSA is performed 100 times, and the optimal solutions are reported in tables for three load types. Furthermore, the main parameters of the SSA are specified as several search agents $(=30)$, and the number of maximum iterations $=80$.

In the present work, the simulation results of each system are divided to three cases; one DG integration, two DG integrations, and three DG integrations with three DG types and three types of loads: $\mathrm{CP}, \mathrm{CI}$, and $\mathrm{CZ}$.

\subsection{IEEE 33-Bus Test System}

This system consists of 33 buses and 32 branches. The total active power of the load is $3715 \mathrm{~kW}$, and the total reactive power of the load is $2300 \mathrm{kVAR}$; the total power loss at base case (B.C) is $211 \mathrm{~kW}$, and the minimum voltage is $0.9040 \mathrm{p} . \mathrm{u}$. on bus 18 . The convergence characteristics of one, two, and three DGs of type I, type II, and Type III for the three loads 
are presented in Figures 5-7, respectively. Figures 8-16 describe the voltage profiles of 1DG, 2DG, and 3DG of the three DG types for the three load types. Furthermore, the power loss comparison between the three types of the load is shown in Figures 17-19.

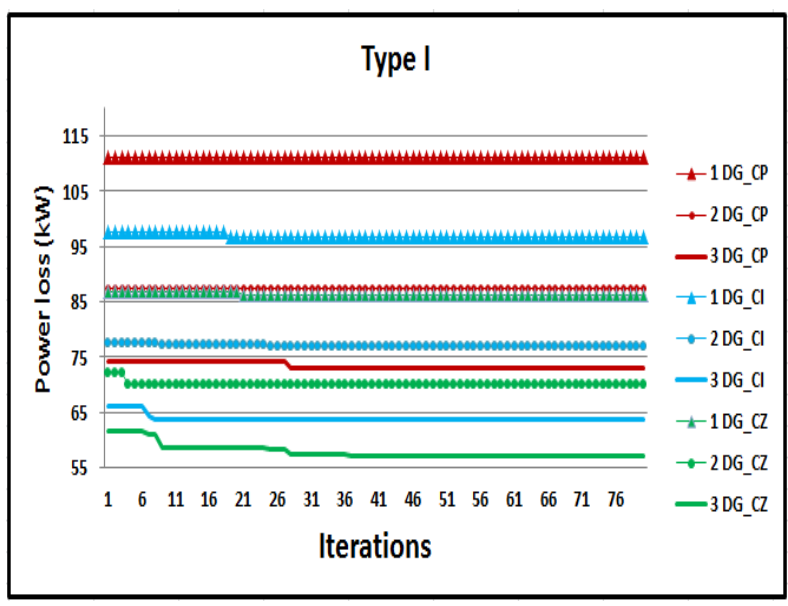

Figure 5. Pl and Iter of DG type I for the three loads.

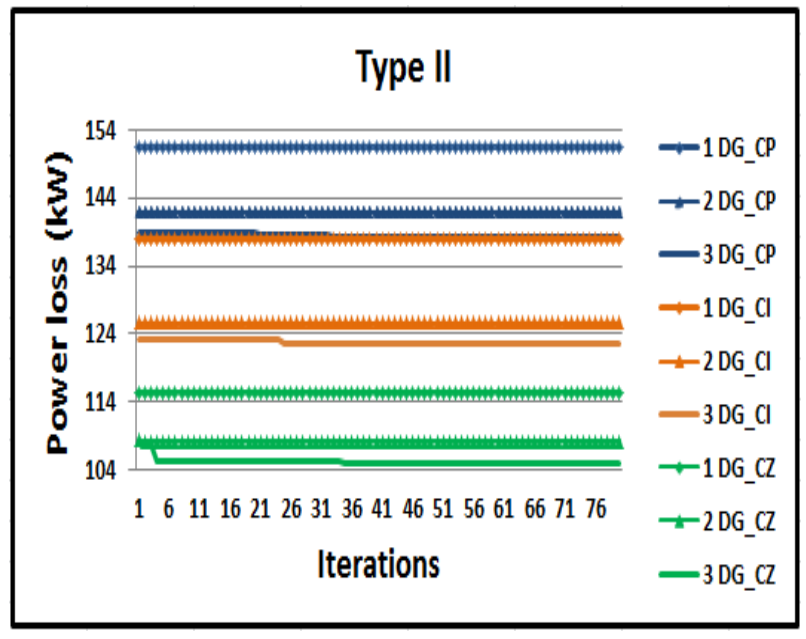

Figure 6. Pl and Iter of DG type II for the three loads.

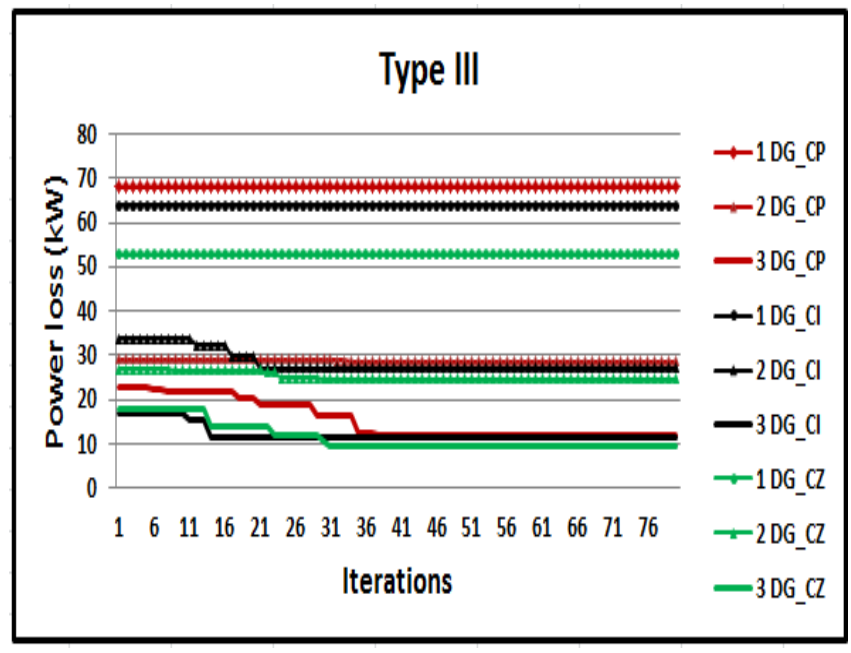

Figure 7. Pl and Iter of DG type III for the three loads. 


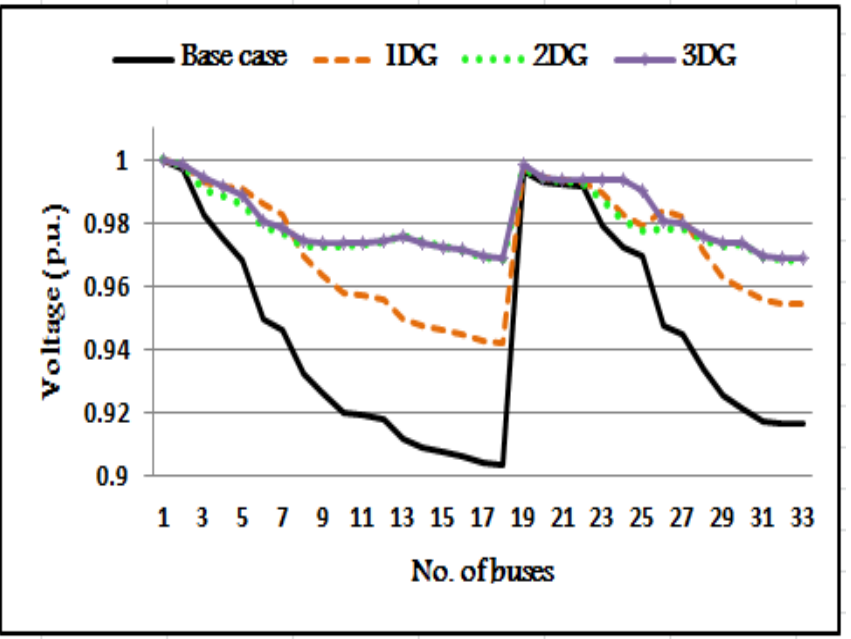

Figure 8. Voltage profile of DG type I for the CP load.

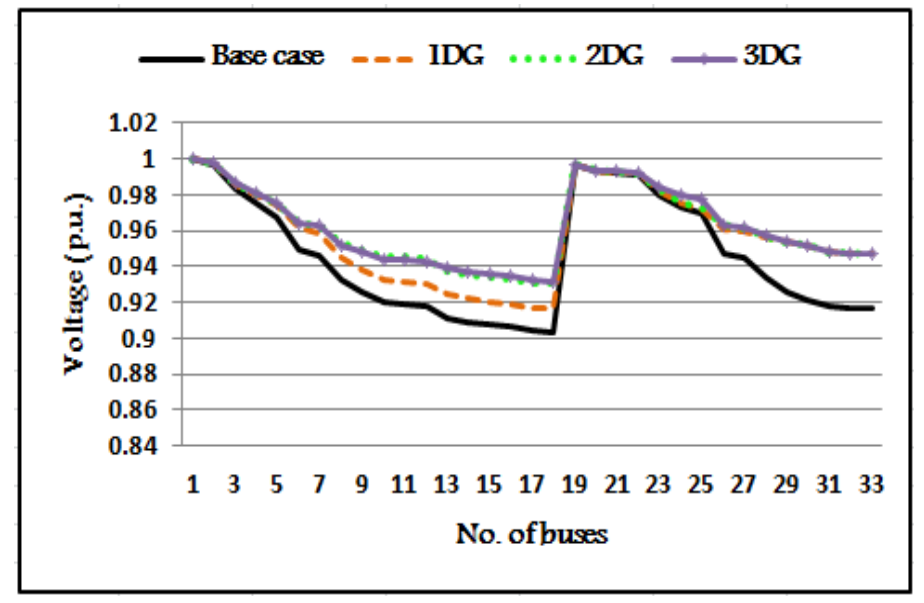

Figure 9. Voltage profile of DG type II for the CP load.

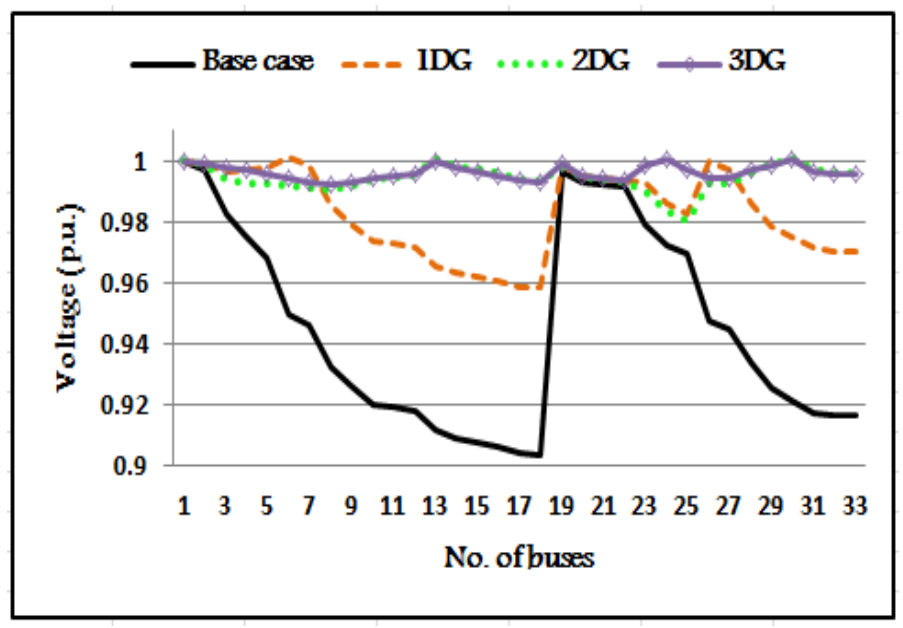

Figure 10. Voltage profile of DG type III for the CP load. 


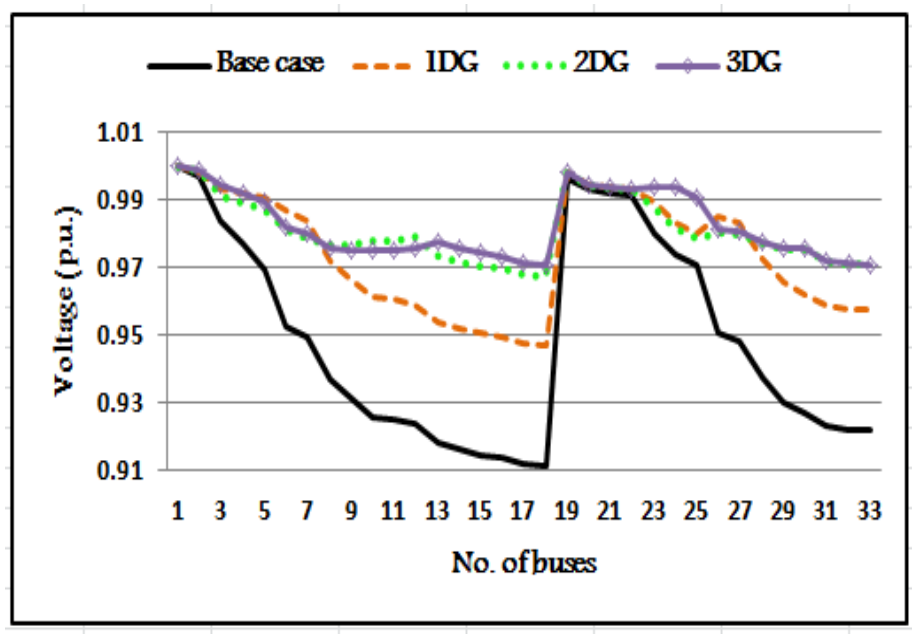

Figure 11. Voltage profile of DG type I for the CI load.

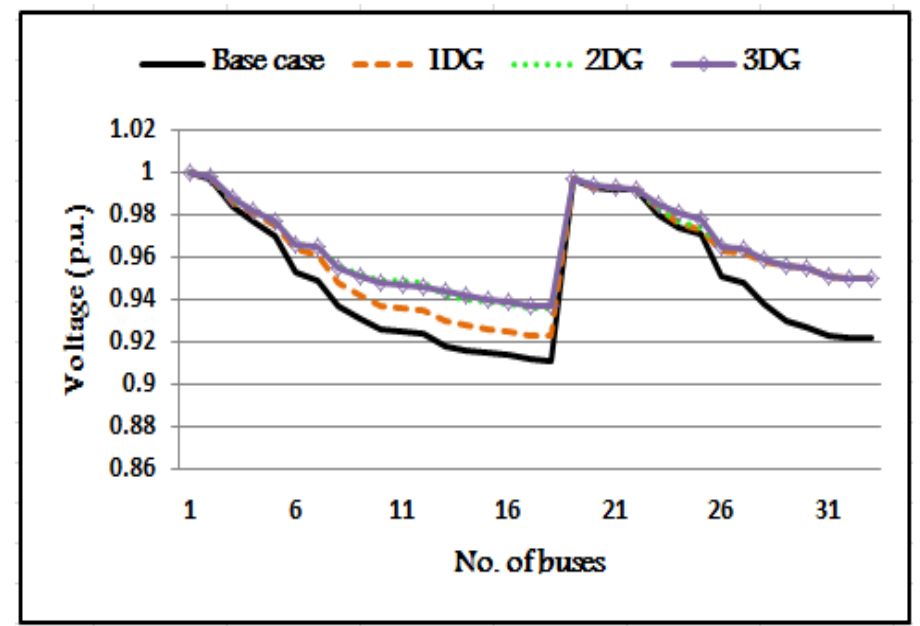

Figure 12. Voltage profile of DG type II for the CI load.

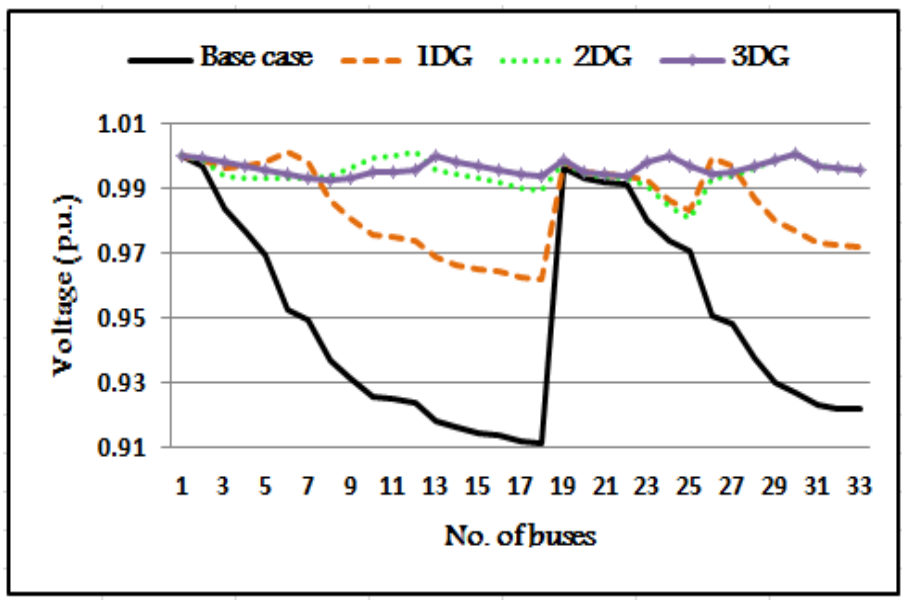

Figure 13. Voltage profile of DG type III for the CI load. 


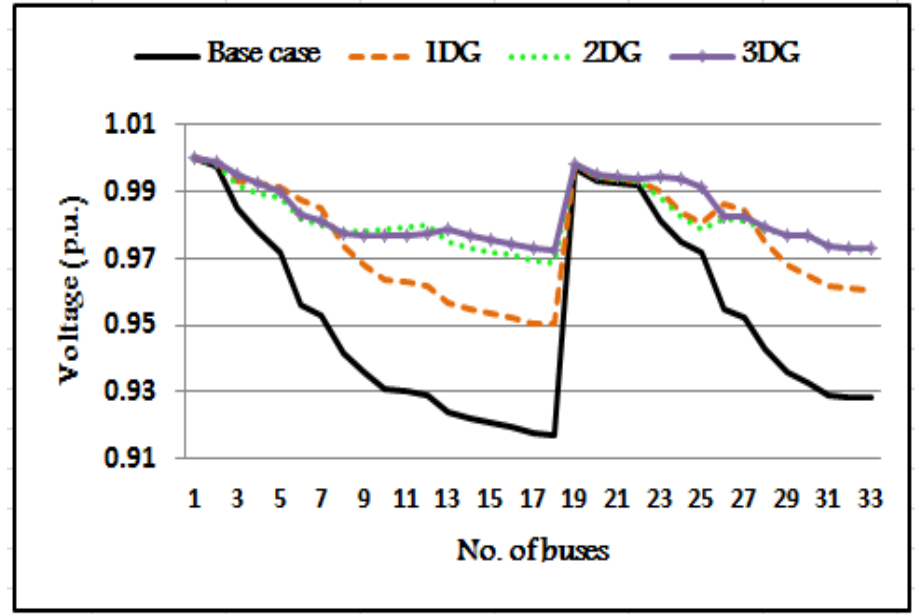

Figure 14. Voltage profile of DG type I for the CZ load.

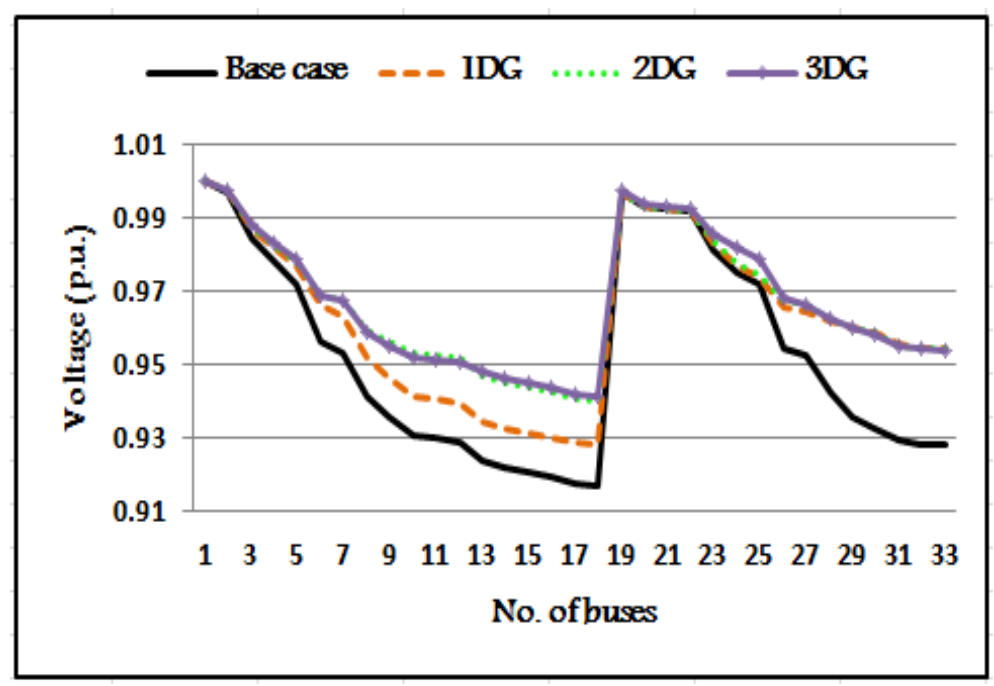

Figure 15. Voltage profile of DG type II for the CZ load.

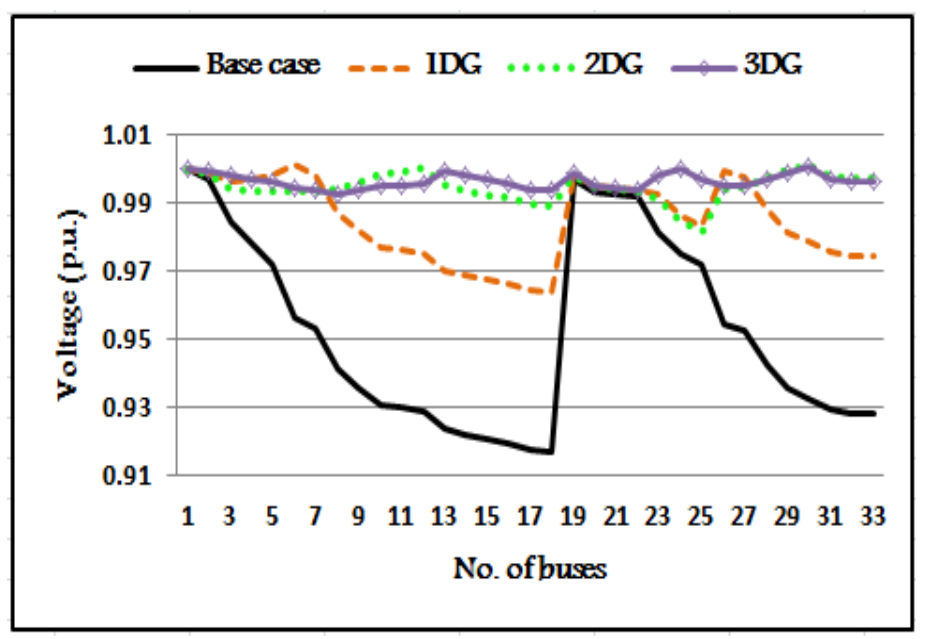

Figure 16. Voltage profile of DG type III for the CZ load. 


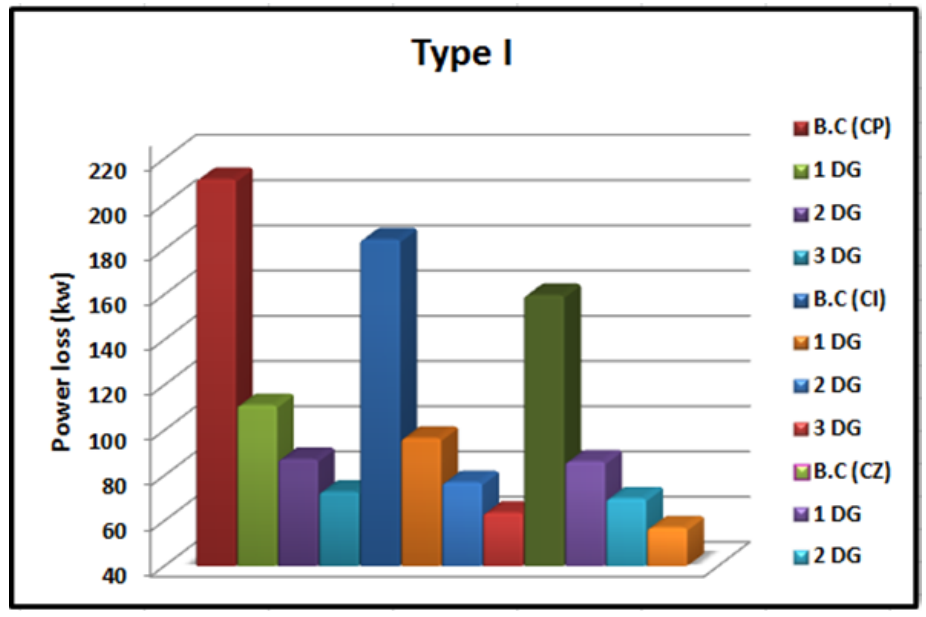

Figure 17. The power loss of DG type I for the three loads.

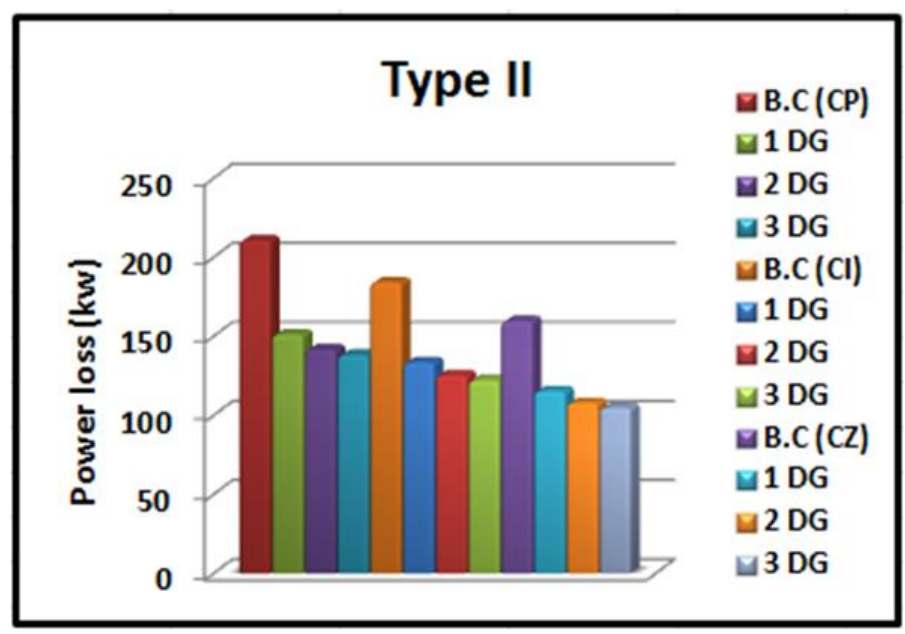

Figure 18. The power loss of DG type II for the three loads.

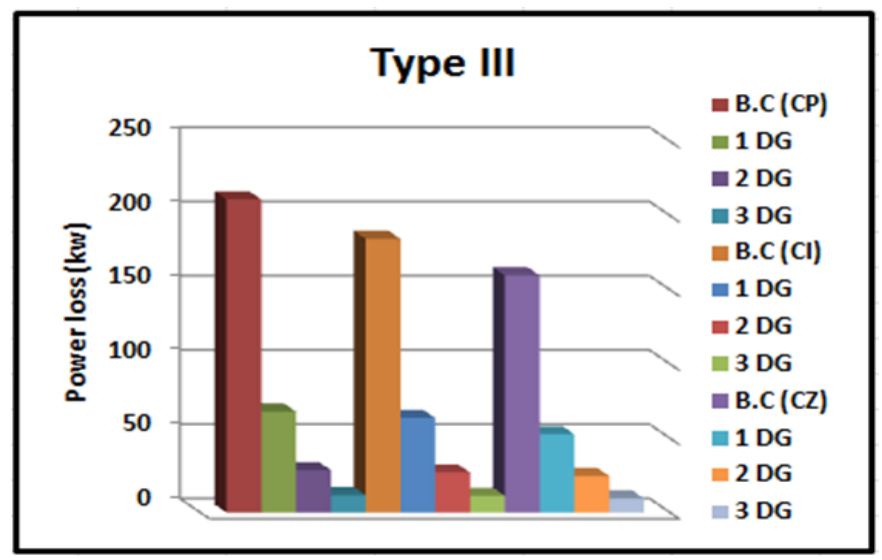

Figure 19. The power loss of DG type III for the three loads.

As shown in the tables, the best results (minimum power losses and maximum voltage profile) are obtained in case of three DGs type III compared with other types of DGs as provide active and reactive power to the system. Furthermore, the results obtained in case of constant impedance is better than the results in other types of loads. 


\subsubsection{Case1: One DG Integration}

For one DG installing, the results are illustrated in Table 1 with the CP, CI, and CZ load types. It is shown from Table 1 that DG type III gives the best simulation results among the other DG types.

Table 1. Optimal results of one DG integration for the three loads on IEEE 33-bus RDS.

\begin{tabular}{|c|c|c|c|c|c|c|c|c|c|c|c|c|}
\hline \multirow{2}{*}{$\begin{array}{c}\begin{array}{c}\text { Type of } \\
\text { Load }\end{array} \\
\text { DG type }\end{array}$} & \multicolumn{4}{|c|}{ CP Type Load } & \multicolumn{4}{|c|}{ CI Type Load } & \multicolumn{4}{|c|}{ CZ Type Load } \\
\hline & B.C & & DG type & & B.C & & DG type & & B.C & & DG type & \\
\hline $\begin{array}{l}\text { Location } \\
\text { Size }\end{array}$ & & $\begin{array}{c}\text { Type-I } \\
6 \\
2.490\end{array}$ & $\begin{array}{c}\text { Type-II } \\
30 \\
1.23\end{array}$ & $\begin{array}{c}\text { Type-III } \\
30 \\
3.028\end{array}$ & & $\begin{array}{c}\text { Type-I } \\
6 \\
2.352\end{array}$ & $\begin{array}{c}\text { Type-II } \\
30 \\
1.144\end{array}$ & $\begin{array}{c}\text { Type-III } \\
6 \\
2.844\end{array}$ & & $\begin{array}{c}\text { Type-I } \\
6 \\
2.166\end{array}$ & $\begin{array}{c}\text { Type-II } \\
30 \\
1.080\end{array}$ & $\begin{array}{c}\text { Type-III } \\
6 \\
2.648\end{array}$ \\
\hline $\begin{array}{c}\text { Total } \\
\text { capacity }\end{array}$ & & 2.490 & 1.23 & 3.028 & & 2.352 & 1.144 & 2.844 & & 2.166 & 1.080 & 2.648 \\
\hline $\begin{array}{l}\text { Power loss } \\
\text { (P.L) }\end{array}$ & 210.997 & 111.17 & 151.41 & 67.95 & 184.3557 & 96.6 & 133.6 & 63.7 & 159.78 & 86.2 & 115.4 & 52.7 \\
\hline V. $\min$ (p.u.) & 0.9038 & 0.9410 & 0.9162 & 0.9570 & 0.9113 & 0.9460 & 0.9226 & 0.9664 & 0.9173 & 0.9491 & 0.9280 & 0.9632 \\
\hline $\begin{array}{l}\text { Min voltage } \\
\text { bus }\end{array}$ & (18) & (18) & (18) & (18) & (18) & (18) & (18) & (18) & (18) & (18) & (18) & (18) \\
\hline $\begin{array}{l}\text { P.L Reduc- } \\
\text { tion\% }\end{array}$ & & 47.31 & 28.24 & 67.795 & & 47.07 & 26.79 & 65.10 & & 46.53 & 28.41 & 67.31 \\
\hline
\end{tabular}

For the CP load: Bus 6 is the optimal bus for DG type I with size 2.490 MW, bus 30 for DG type II, and DG type III with sizes 1.23 MVAR and 3.028 MVA, respectively; the active power loss decreased from $210.997 \mathrm{~kW}$ to111.17 kW for DG type I, $151.41 \mathrm{~kW}$ for DG type II, and $67.95 \mathrm{~kW}$ for DG type III.

For the CI load: Bus 6 is specified as the optimal bus for DG type I with size $2.352 \mathrm{MW}$, bus 30 for DG type II with size 1.144 MVAR, and bus 6 for DG type III with size 2.844 MVA. The active power loss decreased from $184.355 \mathrm{~kW}$ to $96.6 \mathrm{~kW}$ at DG type I, $133.6 \mathrm{~kW}$ for DG type II, and $63.7 \mathrm{~kW}$ for DG type III.

For the CZ load: Bus 6 is specified as the optimal bus for DG type I with size 2.166 MW, bus 30 for DG type II with size 1.080 MVAR, and bus 6 for DG type III with size 2.648MVA. The power loss decreased from $159.78 \mathrm{~kW}$ to $86.2 \mathrm{~kW}$ for DG type I, $115.4 \mathrm{~kW}$ for DG type II, and $52.7 \mathrm{~kW}$ for DG type III.

\subsubsection{Case2: Two DGs Integration}

For two DG installation, Table 2 illustrates the results of optimal allocation of three types of DGs for three load types.

For the CP load: the power loss reduced from $210.997 \mathrm{~kW}$ to $87.2876 \mathrm{~kW}$ for DG type I, $141.935 \mathrm{~kW}$ for DG type II, and $28.56 \mathrm{~kW}$ for DG type III.

For the CI load: Bus 12 and 30 were chosen as the best locations for three DG types of DG, and the power loss reduced from $184.3557 \mathrm{~kW}$ to $77 \mathrm{~kW}, 125.6 \mathrm{~kW}$, and $27 \mathrm{~kW}$ for DG type I, DG type II, and DG type III, respectively.

For the CZ load: the power loss reduced from $159.78 \mathrm{~kW}$ to $69.9 \mathrm{~kW}, 108 \mathrm{~kW}$, and $24.6 \mathrm{~kW}$ for DG type I, DG type II, and DG type III, respectively, when the DGs were installed at bus 12 and 30 for the three types of DGs. 
Table 2. Optimal results of two DG integration for three types of loads on the IEEE 33-bus RDS.

\begin{tabular}{|c|c|c|c|c|c|c|c|c|c|c|c|c|}
\hline \multirow{2}{*}{$\begin{array}{c}\begin{array}{c}\text { Type of } \\
\text { Load }\end{array} \\
\text { DG type }\end{array}$} & \multicolumn{4}{|c|}{ CP Type Load } & \multicolumn{4}{|c|}{ CI Type Load } & \multicolumn{4}{|c|}{ CZ Type Load } \\
\hline & B.C & & DG type & & B.C & & DG type & & B.C & & DG type & \\
\hline $\begin{array}{c}\text { Location } \\
\text { Size }\end{array}$ & & $\begin{array}{c}\text { Type-I } \\
13 \\
30 \\
0.832 \\
1.110\end{array}$ & $\begin{array}{c}\text { Type-II } \\
12 \\
30 \\
0.430 \\
1.044\end{array}$ & $\begin{array}{c}\text { Type-III } \\
13 \\
30 \\
0.920 \\
1.529\end{array}$ & & $\begin{array}{c}\text { Type-I } \\
12 \\
30 \\
0.869 \\
1.014\end{array}$ & $\begin{array}{c}\text { Type-II } \\
12 \\
30 \\
0.400 \\
0.971\end{array}$ & $\begin{array}{c}\text { Type-III } \\
12 \\
30 \\
0.962 \\
1.396\end{array}$ & & $\begin{array}{c}\text { Type-I } \\
12 \\
30 \\
0.806 \\
0.929\end{array}$ & $\begin{array}{c}\text { Type-II } \\
12 \\
30 \\
0.391 \\
0.911\end{array}$ & $\begin{array}{c}\text { Type-III } \\
12 \\
30 \\
0.9 \\
1.29\end{array}$ \\
\hline $\begin{array}{c}\text { Total } \\
\text { capacity }\end{array}$ & & 1.942 & 1.47 & 2.449 & & 1.883 & 1.372 & 2.358 & & 1.734 & 1.303 & 2.19 \\
\hline $\begin{array}{l}\text { Power loss } \\
\text { (P.L) }\end{array}$ & 210.997 & 87.2876 & 141.935 & 28.56 & 184.356 & 77 & 125.6 & 27 & 159.78 & 69.9 & 108 & 24.6 \\
\hline V. min (p.u.) & 0.9038 & 0.9667 & 0.9290 & 0.9801 & 0.9113 & 0.9659 & 0.9344 & 0.9836 & 0.9173 & 0.9675 & 0.9394 & 0.9814 \\
\hline $\begin{array}{c}\text { Min voltage } \\
\text { bus }\end{array}$ & (18) & (33) & (18) & $(25)$ & (18) & (18) & (18) & $(25)$ & (18) & (18) & (18) & (25) \\
\hline $\begin{array}{c}\text { P.L } \\
\text { reduction } \%\end{array}$ & & 58.63 & 32.73 & 86.46 & & 57.81 & 31.2 & 85.21 & & 56.64 & 33.00 & 84.74 \\
\hline $\mathrm{PF}$ & & & & $\begin{array}{l}0.91 \\
0.72\end{array}$ & & - & & $\begin{array}{l}0.91 \\
0.72\end{array}$ & & & & $\begin{array}{l}0.90 \\
0.71\end{array}$ \\
\hline
\end{tabular}

\subsubsection{Case 3: Three DGs Integration}

For the installation of three DGs, the optimal allocation of the three types of DGs are 13, 24, and 30 for the CP, CI, and CZ load types, as obtained in Table 3; the power loss reduction is at its maximum in the case of the type III DGs in all three types of load among the other types, as they inject active and reactive power.

Table 3. Optimal results of the three DGs' integration for three types of loads on an IEEE 33 bus.

\begin{tabular}{|c|c|c|c|c|c|c|c|c|c|c|c|c|}
\hline $\begin{array}{c}\text { Type of } \\
\text { Load }\end{array}$ & \multicolumn{4}{|c|}{ CP Type Load } & \multicolumn{4}{|c|}{ CI Type Load } & \multicolumn{4}{|c|}{ CZ Type Load } \\
\hline DG twne & B.C & & DG type & & B.C & & DG type & & B.C & & DG type & \\
\hline Location & & $\begin{array}{c}\text { Type-I } \\
13 \\
24 \\
30 \\
0.79 \\
1.07 \\
1.012\end{array}$ & $\begin{array}{c}\text { Type-II } \\
13 \\
24 \\
30 \\
0.359 \\
0.52 \\
1.016\end{array}$ & $\begin{array}{c}\text { Type-III } \\
13 \\
24 \\
30 \\
0.869 \\
1.189 \\
1.425\end{array}$ & & $\begin{array}{c}\text { Type-I } \\
13 \\
24 \\
30 \\
0.725 \\
0.958 \\
1.046\end{array}$ & $\begin{array}{c}\text { Type-II } \\
13 \\
24 \\
30 \\
0.334 \\
0.490 \\
0.944\end{array}$ & $\begin{array}{c}\text { Type-III } \\
13 \\
24 \\
30 \\
0.802 \\
1.175 \\
1.337\end{array}$ & & $\begin{array}{c}\text { Type-I } \\
13 \\
24 \\
30 \\
0.672 \\
1.015 \\
0.871\end{array}$ & $\begin{array}{c}\text { Type-II } \\
13 \\
24 \\
30 \\
0.324 \\
0.490 \\
0.884\end{array}$ & $\begin{array}{c}\text { Type-III } \\
13 \\
24 \\
30 \\
0.750 \\
1.128 \\
1.234\end{array}$ \\
\hline $\begin{array}{c}\text { Total } \\
\text { capacity }\end{array}$ & & 2.87 & 1.890 & 3.483 & & 2.730 & 1.769 & 3.297 & & 2.558 & 1.699 & 3.112 \\
\hline $\begin{array}{l}\text { Power loss } \\
\text { (P.L) }\end{array}$ & 210.997 & 72.89 & 138.37 & 11.77 & 184.3557 & 63.6 & 122.4 & 11.3 & 159.78 & 57 & 104.9 & 9.5 \\
\hline V. min (p.u.) & 0.9038 & 0.9670 & 0.9303 & 0.9905 & 0.9113 & 0.9695 & 0.9356 & 0.9918 & 0.9173 & 0.9713 & 0.9405 & 0.9925 \\
\hline $\begin{array}{c}\text { Min voltage } \\
\text { bus }\end{array}$ & (18) & (33) & (18) & (8) & (18) & (33) & (18) & (8) & (18) & (18) & (18) & (8) \\
\hline $\begin{array}{l}\text { P.L } \\
\text { reduction \% }\end{array}$ & - & 65.45 & 34.42 & 94.42 & & 65.15 & 32.93 & 93.81 & & 64.64 & 34.92 & 94.11 \\
\hline PF & & & & $\begin{array}{l}0.91 \\
0.90 \\
0.71\end{array}$ & & - & & $\begin{array}{l}0.91 \\
0.91 \\
0.71\end{array}$ & & & & $\begin{array}{l}0.90 \\
0.90 \\
0.70\end{array}$ \\
\hline
\end{tabular}

Furthermore, the power losses for the three previous tables with the number of iterations are shown in Figures 5-7.

For the CP load: the power loss reached $72.89 \mathrm{~kW}$ in DG type I, $138.37 \mathrm{~kW}$ in DG type II, and $11.77 \mathrm{~kW}$ in DG type III from B.C $210.997 \mathrm{~kW}$.

In order to further emphasize the strength of the proposed method, Table 4 illustrates a comparison between the proposed method results and other techniques for the $\mathrm{CP}$ load case; the maximum benefit can be achieved at this case as the number of the DGs which inject active and reactive power are increased, so that the minimum power losses are achieved and the voltages of all of the buses are improved when the three DGs are placed at the optimal locations, with optimal power factors of $0.91,0.90$, and 0.71 , respectively. 
Table 4. Optimal results of the three DGs for type III compared with other techniques for CP loads on an IEEE 33 bus.

\begin{tabular}{|c|c|c|c|c|c|c|c|c|c|c|}
\hline Case & Technique & & $\begin{array}{l}\text { Loc } \\
\text { Size }\end{array}$ & $\begin{array}{l}\text { ion } \\
\text { IVA) }\end{array}$ & & $\begin{array}{l}\text { Total Capacity } \\
\text { (MVA) }\end{array}$ & $\begin{array}{c}\text { Power } \\
\text { Loss }\end{array}$ & P.f & $\begin{array}{l}V \min \\
\text { (p.u.) }\end{array}$ & $\begin{array}{c}\text { Loss } \\
\text { Reduction \% }\end{array}$ \\
\hline \multirow{4}{*}{ 3DG } & Proposed & $\begin{array}{l}\text { Bus } \\
\text { Size }\end{array}$ & $\begin{array}{c}13 \\
0.869\end{array}$ & $\begin{array}{c}24 \\
1.189\end{array}$ & $\begin{array}{c}30 \\
1.425\end{array}$ & 3.483 & 11.77 & $\begin{array}{l}0.91 \\
0.90 \\
0.71\end{array}$ & $0.9905(8)$ & 94.42 \\
\hline & GA [26] & $\begin{array}{l}\text { Bus } \\
\text { Size }\end{array}$ & $\begin{array}{c}14 \\
0.8153\end{array}$ & $\begin{array}{c}24 \\
1.102\end{array}$ & $\begin{array}{c}30 \\
1.49\end{array}$ & 3.407 & 11.91 & $\begin{array}{l}0.90 \\
0.89 \\
0.72 \\
\end{array}$ & NA & 94.35 \\
\hline & IA [27] & $\begin{array}{l}\text { Bus } \\
\text { Size }\end{array}$ & $\begin{array}{c}6 \\
1.098\end{array}$ & $\begin{array}{c}30 \\
1.098\end{array}$ & $\begin{array}{c}14 \\
0.768\end{array}$ & 2.964 & 22.29 & $\begin{array}{l}0.82 \\
0.82 \\
0.82 \\
\end{array}$ & $\begin{array}{c}0.99217 \\
(8)\end{array}$ & 89.45 \\
\hline & PABC [28] & $\begin{array}{l}\text { Bus } \\
\text { Size }\end{array}$ & $\begin{array}{c}12 \\
1.014\end{array}$ & $\begin{array}{c}25 \\
0.960\end{array}$ & $\begin{array}{c}30 \\
1.363\end{array}$ & 2.889 & 15.91 & $\begin{array}{l}0.85 \\
0.85 \\
0.85\end{array}$ & NA & 92.46 \\
\hline
\end{tabular}

The proposed method achieves a power loss reduction of $94.42 \%$, which is better than other techniques, e.g., 89.45\% and 89.43 in Improved Analytical (IA) [27] and Particle Artificial Bee Colony algorithm (PABC) [28].

For the CI load: the B.C power losses are $184.3557 \mathrm{~kW}$; the power losses obtained in the case of inserting three DGs of DG type I is $63.6 \mathrm{~kW}$, DG type II is $122.4 \mathrm{~kW}$, and DG type III is $11.3 \mathrm{~kW}$.

For the CZ load: the power loss reached $57 \mathrm{~kW}$ in DG type I, $104.9 \mathrm{~kW}$ in DG type II, and $9.5 \mathrm{~kW}$ in DG type III from B.C $159.78 \mathrm{~kW}$.

\subsection{IEEE 69-Bus Test System}

This system consists of 69 buses and 68 branches, as shown in Figure 6; the total active and reactive power of the load are $3801.49 \mathrm{~kW}$ and 2694.6 KVAR, respectively; the losses at base case (B.C) are $224.997 \mathrm{~kW}$, and the minimum voltage is 0.9091 p.u. at bus 65 . The convergence characteristics of one, two, and three DGs of DG type I, DG type II, and DG type III for the three loads are presented in Figures 20-22, respectively. Figures 23-31 describe the voltage profiles of 1DG, 2DG, and 3DG of the three DG types for the three load types. Furthermore, the power loss comparisons between the three types of load are shown in Figures 32-34.

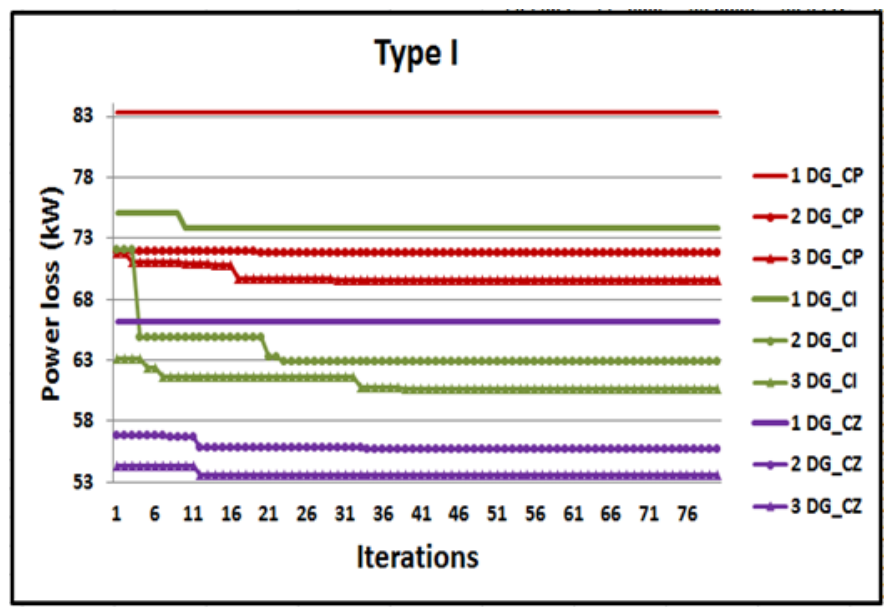

Figure 20. Pl and Iter of DG type I for the three loads. 


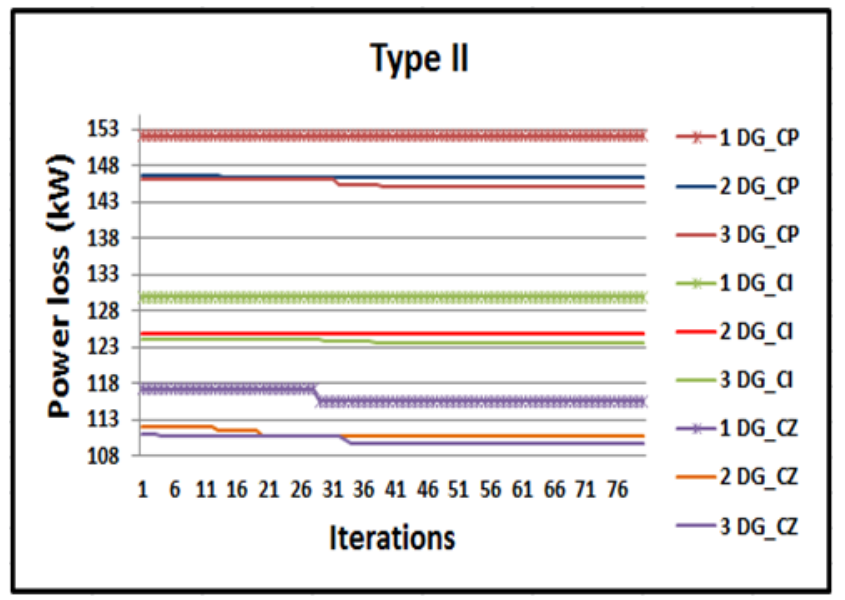

Figure 21. Pl and Iter of DG type II for the three loads.

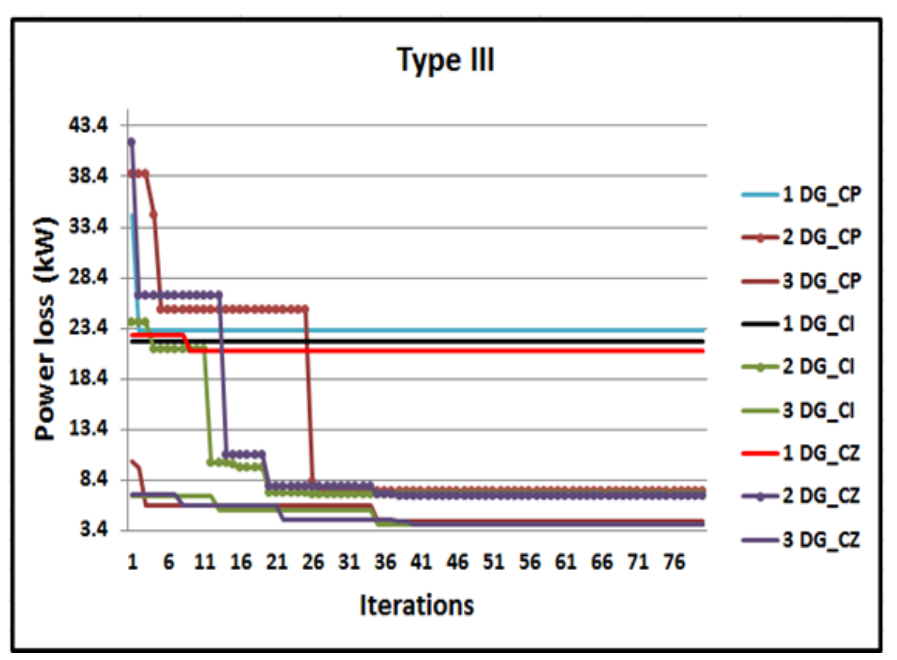

Figure 22. Pl and Iter of DG type III for the three loads.

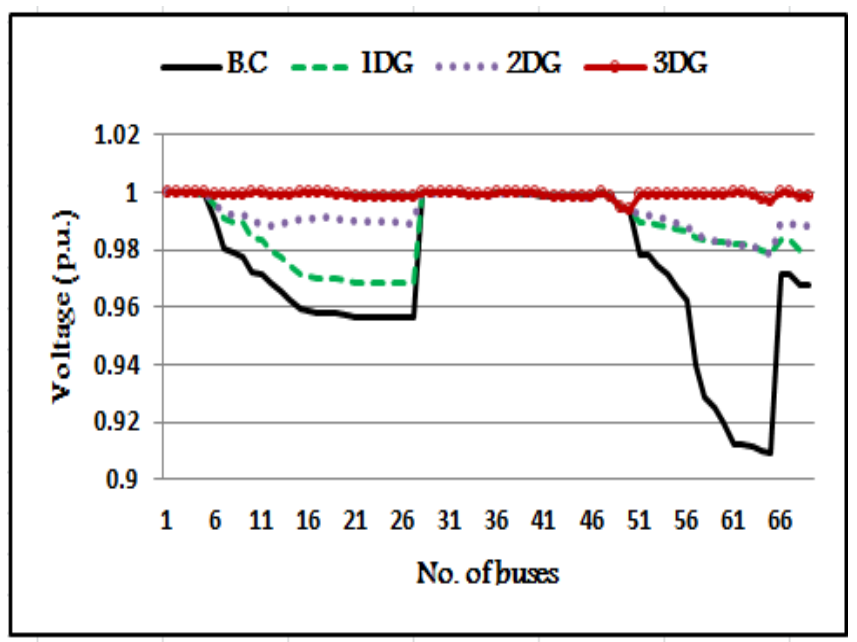

Figure 23. Voltage profile of DG type I for the CP load. 


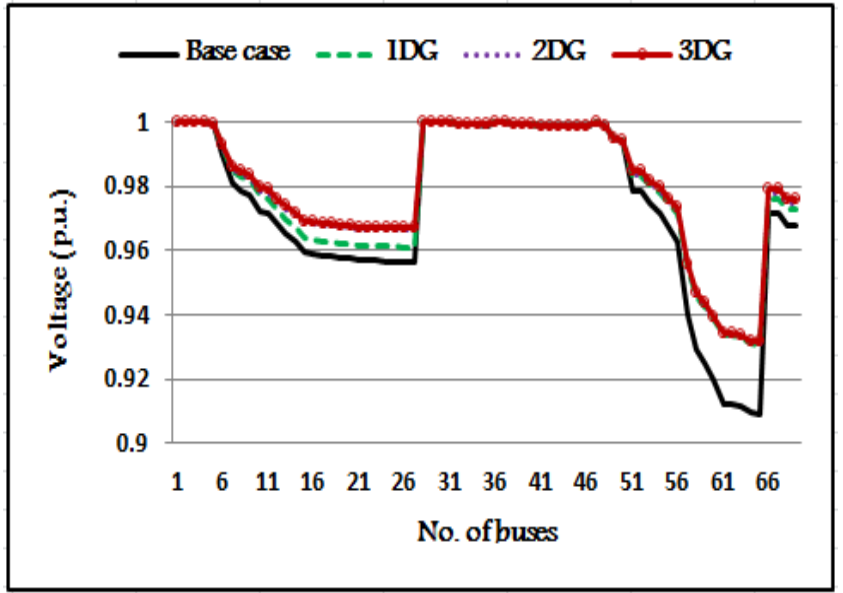

Figure 24. Voltage profile of DG type II for the CP load.

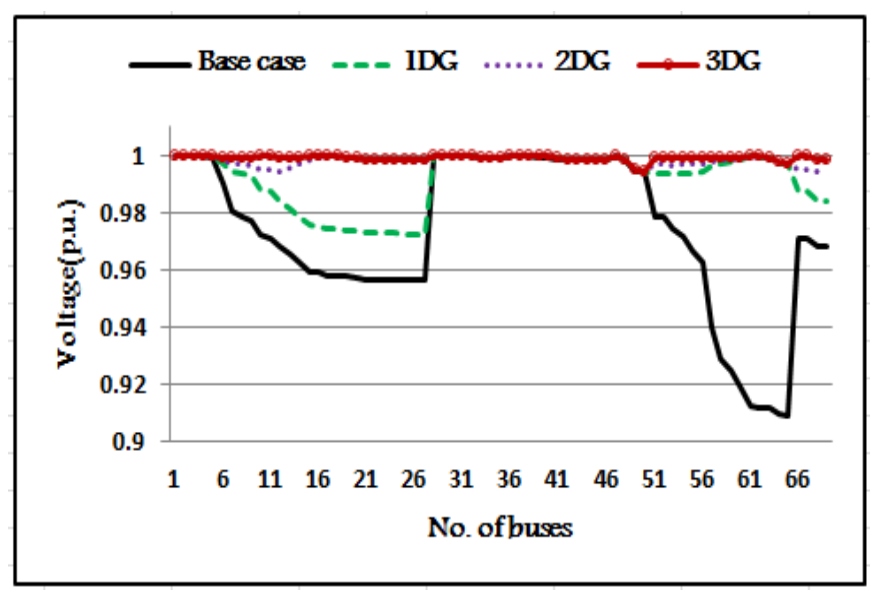

Figure 25. Voltage profile of DG type III for the CP load.

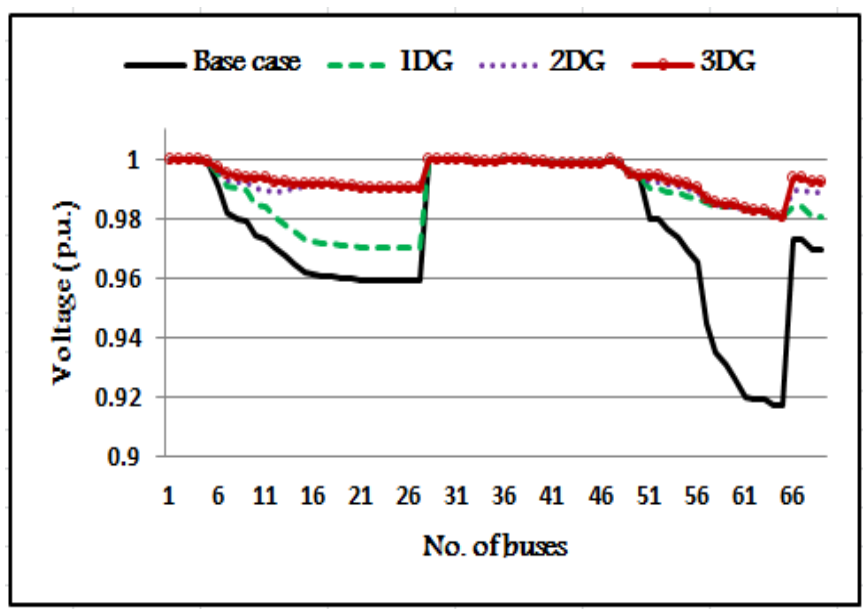

Figure 26. Voltage profile of DG type I for the CI load. 


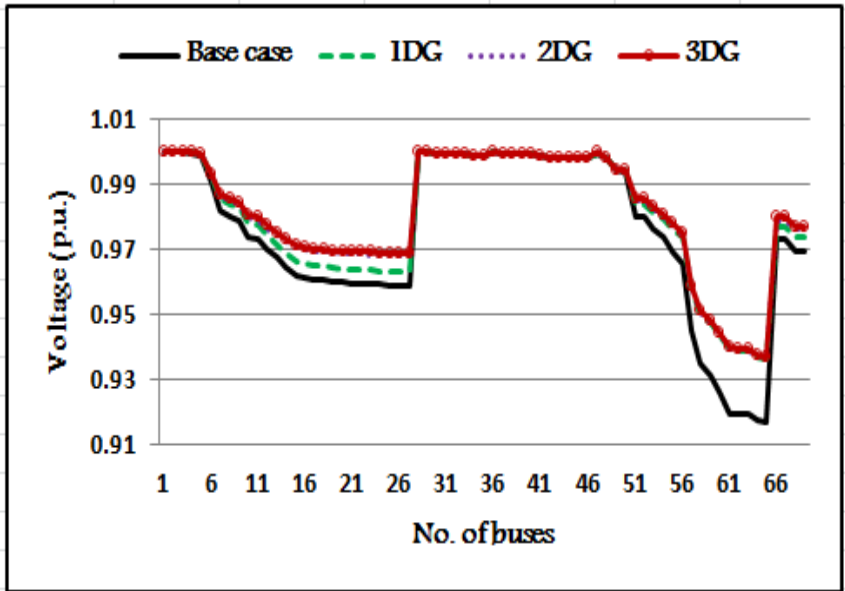

Figure 27. Voltage profile of DG type II for the CI load.

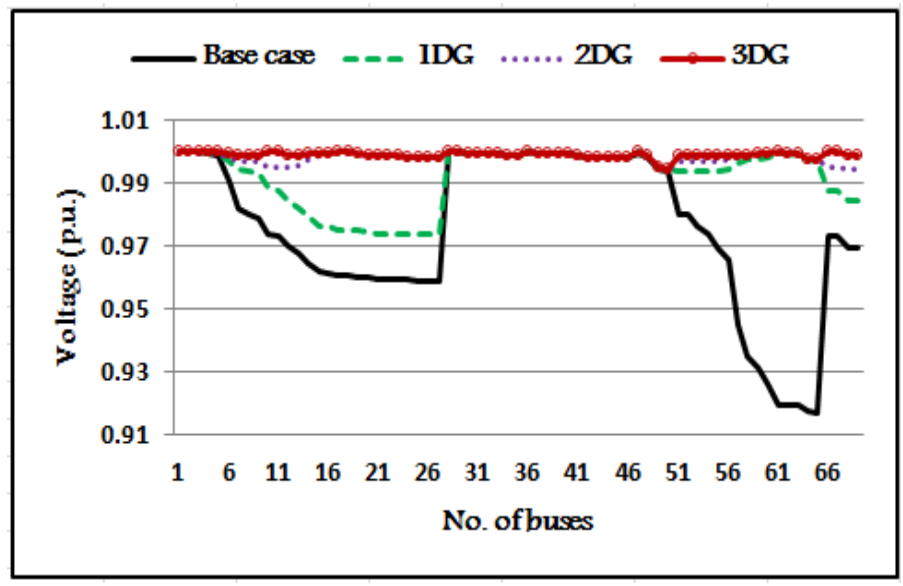

Figure 28. Voltage profile of DG type III for the CI load.

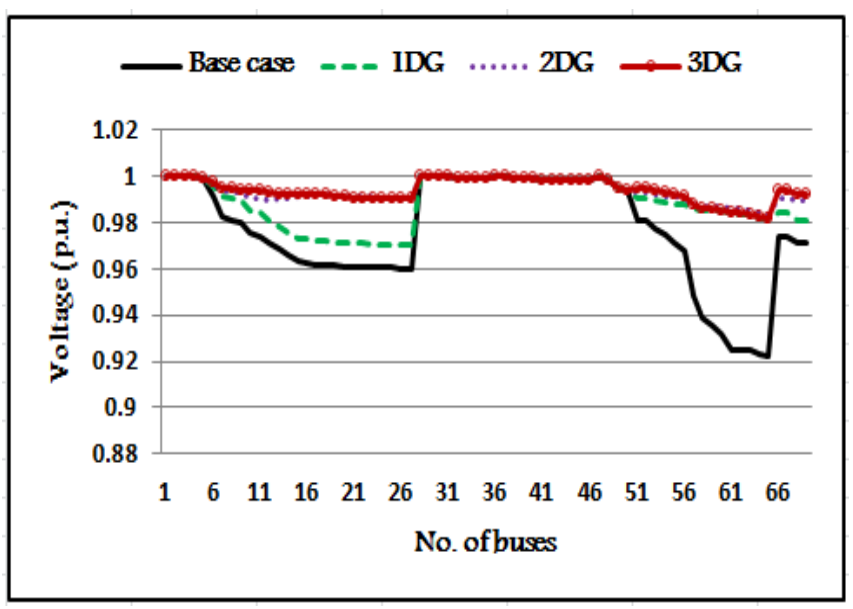

Figure 29. Voltage profile of DG type I for the CZ load. 


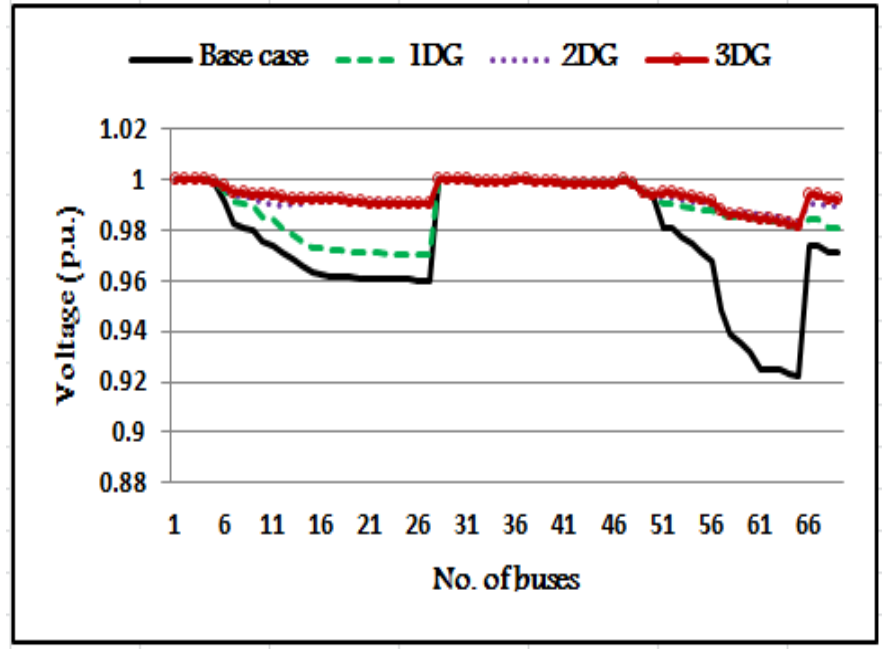

Figure 30. Voltage profile of DG type II for the CZ load.

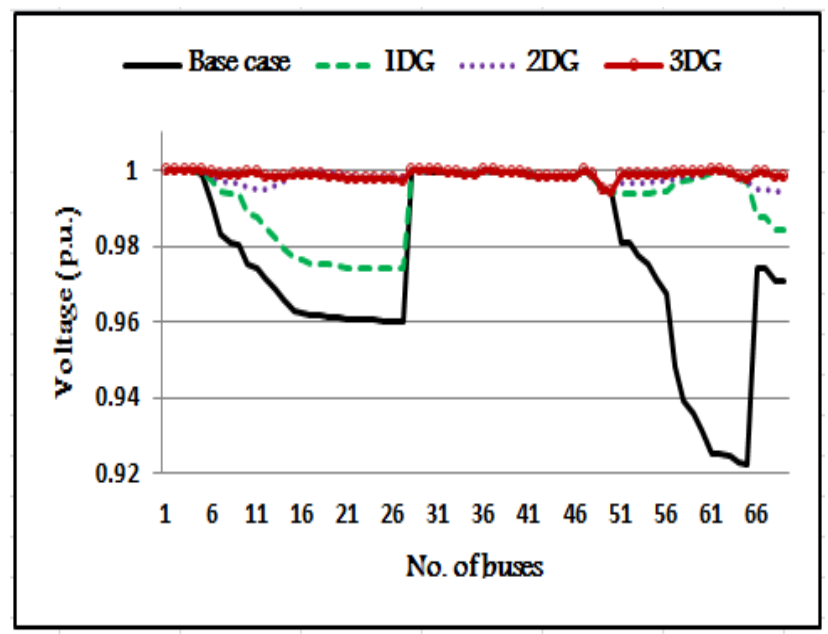

Figure 31. Voltage profile of DG type III for the CZ load.

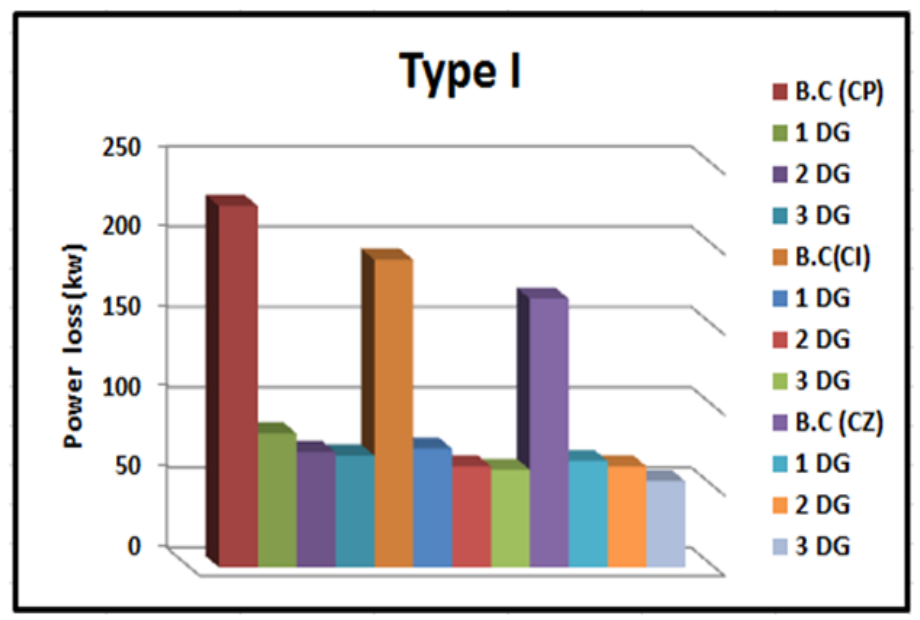

Figure 32. The power loss of DG type I for the three loads. 


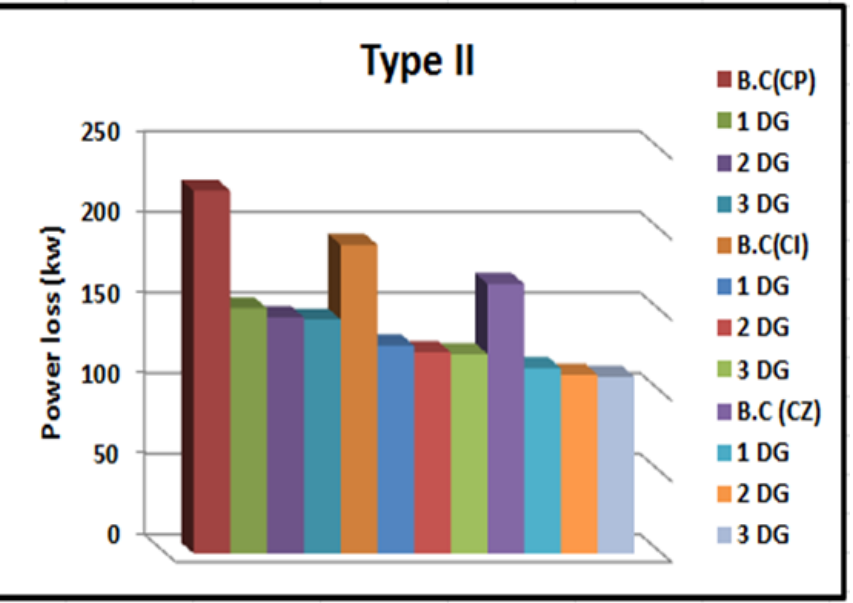

Figure 33. The power loss of DG type II for the three loads.

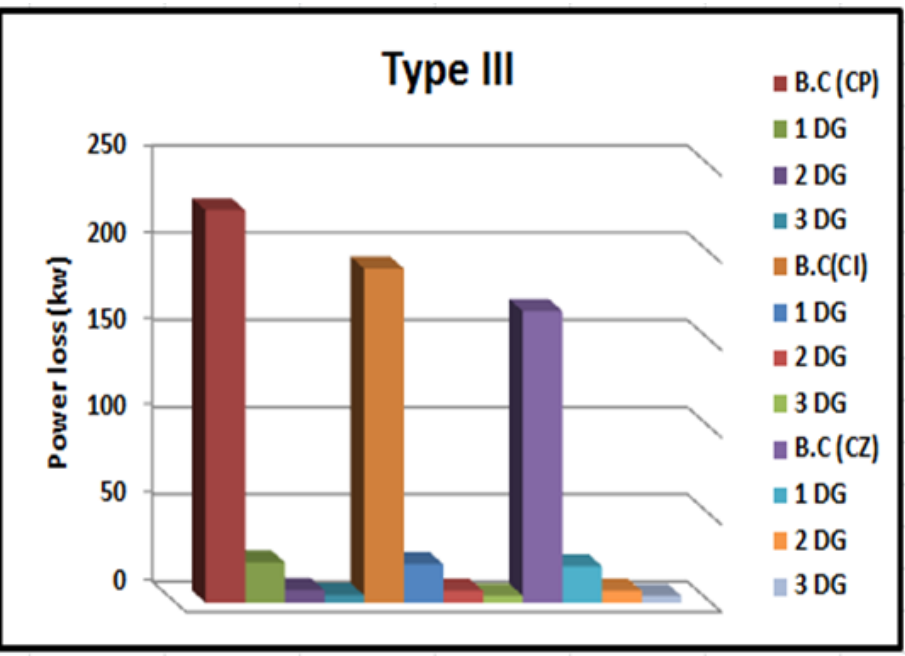

Figure 34. The power loss of DG type III for the three loads.

Similar to the IEEE 33 bus, the minimum power losses in the case of three DGs for type III were constant impedance (CZ) and then constant current (CI), followed by constant power $(\mathrm{CP})$, although most locations of the DGs were the same for the three type of loads. The power factor was improved for three cases.

\subsubsection{Case1: One DG Integration}

For one DG installation, the simulation results are illustrated in Table 5.

For the CP load: Bus 61 is the optimal bus for three types of DG; the power loss decreased from $224.997 \mathrm{~kW}$ to $83.37 \mathrm{~kW}$ for DG type I, $152.09 \mathrm{~kW}$ for DG type II, and $23.15 \mathrm{~kW}$ for DG type III.

For the CI load: Bus 61 is the optimal bus for the three types of DGs; the power loss decreased from $191.5 \mathrm{~kW}$ to $73.87 \mathrm{~kW}$ for DG type I, $129 \mathrm{~kW}$ for DG type II, and $22 \mathrm{~kW}$ for DG type III.

For the CZ load: the power losses reduced from $167.2 \mathrm{~kW}$ at B.C to $66.2 \mathrm{~kW}$ for DG type I, to $115 \mathrm{~kW}$ for DG type II, and to $21 \mathrm{~kW}$ for DG type III when the DG was installed at bus 6 . 
Table 5. Optimal results of one DG integration for three types of loads on an IEEE 69 bus RDS.

\begin{tabular}{|c|c|c|c|c|c|c|c|c|c|c|c|c|}
\hline \multirow{2}{*}{$\begin{array}{c}\begin{array}{c}\text { Type of } \\
\text { Load }\end{array} \\
\text { Case } \\
\end{array}$} & \multicolumn{4}{|c|}{ CP Type Load } & \multicolumn{4}{|c|}{ CI Type Load } & \multicolumn{4}{|c|}{ CZ Type Load } \\
\hline & B.C & & DG type & & B.C & & DG type & & B.C & & DG type & \\
\hline $\begin{array}{l}\text { DG type } \\
\text { Location } \\
\text { Size }\end{array}$ & & $\begin{array}{c}\text { Type-I } \\
61 \\
18.1\end{array}$ & $\begin{array}{c}\text { Type-II } \\
61 \\
1.291\end{array}$ & $\begin{array}{c}\text { Type-III } \\
61 \\
2.22\end{array}$ & & $\begin{array}{c}\text { Type-I } \\
61 \\
1.655\end{array}$ & $\begin{array}{c}\text { Type-II } \\
61 \\
1.202\end{array}$ & $\begin{array}{c}\text { Type-III } \\
61 \\
2.052\end{array}$ & & $\begin{array}{c}\text { Type-I } \\
61 \\
1.594\end{array}$ & $\begin{array}{c}\text { Type-II } \\
61 \\
1.122\end{array}$ & $\begin{array}{c}\text { Type-III } \\
61 \\
1.924\end{array}$ \\
\hline $\begin{array}{c}\text { Total } \\
\text { capacity }\end{array}$ & & 18.1 & 1.291 & 2.22 & & 1.655 & 1.202 & 2.052 & & 1.594 & 1.122 & 1.924 \\
\hline $\begin{array}{l}\text { Power loss } \\
\text { (PL) }\end{array}$ & 224.997 & 83.37 & 152.09 & 23.15 & 191.5 & 73.87 & 129 & 22 & 167.2 & 66.2 & 115 & 21 \\
\hline V. $\min$ (p.u.) & 0.9091 & 0.9679 & 0.9302 & 0.9734 & 0.9167 & 0.9690 & 0.9361 & 0.9740 & 0.9226 & 0.9700 & 0.9402 & 0.9748 \\
\hline $\begin{array}{l}\text { Min voltage } \\
\text { bus }\end{array}$ & (65) & (27) & (65) & (27) & (65) & (27) & (65) & (27) & (65) & (27) & (65) & (27) \\
\hline $\begin{array}{c}\text { P.L } \\
\text { reduction\% }\end{array}$ & & 62.95 & 32.40 & 89.71 & & 61.43 & 32.63 & 88.5 & & 60.40 & 31.22 & 87.44 \\
\hline $\mathrm{PF}$ & & & & 0.81 & & & & 0.81 & & & & 0.81 \\
\hline
\end{tabular}

\subsubsection{Case2: Two DGs Integration}

For two DG installation, the simulation results are illustrated in Table 6.

Table 6. Optimal results of two DG integration for three types of loads on an IEEE 69 bus RDS.

\begin{tabular}{|c|c|c|c|c|c|c|c|c|c|c|c|c|}
\hline \multirow[b]{2}{*}{ Type of load } & \multicolumn{4}{|c|}{ CP Type Load } & \multicolumn{4}{|c|}{ CI Type Load } & \multicolumn{4}{|c|}{ CZ Type Load } \\
\hline & B.C & & DG type & & B.C & & DG type & & B.C & & DG type & \\
\hline DG type & & Type-I & Type-II & Type-III & & Type-I & Type-II & Type-III & & Type-I & Type-II & Type-III \\
\hline Iocation & & 61 & 61 & 61 & & 61 & 61 & 61 & & 61 & 61 & 61 \\
\hline Location & & 17 & 17 & 17 & & 17 & 17 & 17 & & 17 & 17 & 17 \\
\hline Size & & 1.724 & 1.236 & 2.127 & & 1.575 & 1.147 & 1.979 & & 1.583 & 1.069 & 1.834 \\
\hline Total & & 0.518 & 0.35 & 0.626 & & 0.497 & 0.336 & 0.606 & & 0.507 & 0.326 & 0.559 \\
\hline capacity & & 2.24 & 1.586 & 2.752 & & 2.072 & 1.483 & 2.585 & & 2.090 & 1.395 & 2.393 \\
\hline $\begin{array}{l}\text { Power loss } \\
\text { (PL) }\end{array}$ & 224.997 & 71.804 & 146.51 & 7.1857 & 191.5 & 62.87 & 124.84 & 6.87 & 167.2 & 62.82 & 110.9 & 6.8 \\
\hline V. $\min$ (p.u.) & 0.9091 & 0.9769 & 0.9305 & 0.9946 & 0.9167 & 0.9783 & 0.9364 & 0.9946 & 0.9226 & 0.9801 & 0.9405 & 0.9940 \\
\hline $\begin{array}{c}\text { Min voltage } \\
\text { bus }\end{array}$ & (65) & $(65)$ & (65) & (69) & (65) & (65) & (65) & (69) & (65) & (65) & (65) & (69) \\
\hline $\begin{array}{c}\mathrm{PL} \\
\text { reduction\% }\end{array}$ & & 68.09 & 34.88 & 96.8 & & 67.17 & 30.80 & 96.41 & & 66.69 & 33.67 & 95.93 \\
\hline PF & & & & $\begin{array}{l}0.81 \\
0.83\end{array}$ & & & & $\begin{array}{l}0.81 \\
0.83\end{array}$ & & & & $\begin{array}{l}0.81 \\
0.81\end{array}$ \\
\hline
\end{tabular}

For the CP load: the proposed hybrid method chose buses 61 and 17 as the optimal locations for the three types of load, and the power loss reached $71.804 \mathrm{~kW}$ for DG type I. $146.51 \mathrm{~kW}$ for DG type II, and $7.1857 \mathrm{~kW}$ for DG type III from the base case $224.997 \mathrm{~kW}$.

For the CI load: in the constant current load, the power loss reduced from $191.5 \mathrm{~kW}$ to $62.87 \mathrm{~kW}, 124.84 \mathrm{~kW}$, and $6.87 \mathrm{~kW}$ for DG type I, DG type II, and DG type III, respectively.

For the CZ load: the power loss was reduced from $167.2 \mathrm{~kW}$ at B.C to $62.82 \mathrm{~kW}$ for DG type I, to $110.9 \mathrm{~kW}$ for DG type II, and to $6.8 \mathrm{~kW}$ for DG type III when the DGs were installed at bus 61 and 17, which are the best locations for the three types of the DG.

5.2.3. Case 3: Three DG Integration

For three DGs installation, the simulation results are illustrated in Table 7. 
Table 7. Optimal results of the three DG integration for the three loads on an IEEE 69-bus RDS.

\begin{tabular}{|c|c|c|c|c|c|c|c|c|c|c|c|c|}
\hline \multirow{2}{*}{$\begin{array}{c}\begin{array}{c}\text { Type of } \\
\text { Load }\end{array} \\
\text { DG type }\end{array}$} & \multicolumn{4}{|c|}{ CP Type Load } & \multicolumn{4}{|c|}{ CI Type Load } & \multicolumn{4}{|c|}{ CZ Type Load } \\
\hline & B.C & & DG type & & B.C & & DG type & & B.C & & DG type & \\
\hline $\begin{array}{l}\text { Location } \\
\text { Size }\end{array}$ & & $\begin{array}{c}\text { Type-I } \\
11 \\
18 \\
61 \\
0.499 \\
0.377 \\
1.668\end{array}$ & $\begin{array}{c}\text { Type-II } \\
11 \\
21 \\
61 \\
0.368 \\
0.231 \\
1.196\end{array}$ & $\begin{array}{c}\text { Type-III } \\
11 \\
18 \\
61 \\
0.616 \\
0.452 \\
2.050\end{array}$ & & $\begin{array}{c}\text { Type-I } \\
11 \\
18 \\
61 \\
0.491 \\
0.359 \\
1.520\end{array}$ & $\begin{array}{c}\text { Type-II } \\
11 \\
18 \\
61 \\
0.336 \\
0.241 \\
1.109\end{array}$ & $\begin{array}{c}\text { Type-III } \\
11 \\
18 \\
61 \\
0.604 \\
0.438 \\
1.884\end{array}$ & & $\begin{array}{c}\text { Type-I } \\
11 \\
18 \\
61 \\
0.493 \\
0.358 \\
1.427\end{array}$ & $\begin{array}{c}\text { Type-II } \\
11 \\
18 \\
61 \\
0.336 \\
0.231 \\
1.031\end{array}$ & $\begin{array}{c}\text { Type-III } \\
11 \\
18 \\
61 \\
0.602 \\
0.425 \\
1.758\end{array}$ \\
\hline $\begin{array}{c}\text { Total } \\
\text { capacity }\end{array}$ & & 2.545 & 1.795 & 3.119 & & 2.370 & 1.686 & 2.926 & & 2.278 & 1.597 & 2.785 \\
\hline $\begin{array}{l}\text { Power loss } \\
\text { (P.L) }\end{array}$ & 224.997 & 69.5456 & 145.21 & 4.25 & 191.5 & 60.70 & 123.67 & 4 & 167.2 & 53.6 & 109.7 & 3.9 \\
\hline V. min (p.u.) & 0.9091 & 0.9770 & 0.9307 & 0.9972 & 0.9167 & 0.9785 & 0.9367 & 0.9974 & 0.9226 & 0.9802 & 0.9408 & 0.9975 \\
\hline $\begin{array}{c}\text { Min voltage } \\
\text { bus }\end{array}$ & (65) & $(65)$ & (65) & (65) & (65) & (65) & (65) & (65) & (65) & (65) & (65) & $(50)$ \\
\hline $\begin{array}{l}\text { P.L } \\
\text { reduction \% }\end{array}$ & - & 69.09 & 35.46 & 98.11 & & 68.3 & 35.42 & 97.91 & & 67.94 & 34.39 & 97.67 \\
\hline PF & & & & $\begin{array}{l}0.82 \\
0.81 \\
0.81\end{array}$ & & - & & $\begin{array}{l}0.82 \\
0.84 \\
0.81\end{array}$ & & & & $\begin{array}{l}0.82 \\
0.84 \\
0.81\end{array}$ \\
\hline
\end{tabular}

For CP load: the proposed hybrid method specified buses 61,18 , and 11 as the optimal locations for type I and type III, while the buses 11, 21, and 61 are the best for DG type II, and the power losses reached $69.5456 \mathrm{~kW}$ for DG type I, $145.21 \mathrm{~kW}$ for DG type II, and $4.25 \mathrm{~kW}$ for DG type III from B.C $224.997 \mathrm{~kW}$. It was observed that DG type III obtained less power loss compared with the others.

In a 69-bus system, the proposed method achieved the best results compared with the other techniques in the case of three DG integration for type III, as shown in Table 8, when the three DGs are placed at 11,21, and 61; with an optimal power factor of $0.82,0.81$, and 0.81 , respectively, the power loss reduction for the proposed method is $98.11 \%$, which is better than 98.10 in the Hybrid PSO-Analytical [26] and 96.84 in the combined power loss sensitivity (CPLS).

Table 8. Optimal results of three DGs for type III compared with the other techniques for CP loads on an IEEE 69 bus.

\begin{tabular}{|c|c|c|c|c|c|c|c|c|c|c|}
\hline Case & Technique & & $\begin{array}{l}\text { (Lo } \\
\text { Size }\end{array}$ & $\begin{array}{l}\text { on) } \\
\text { VA) }\end{array}$ & & $\begin{array}{c}\text { Total Capacity } \\
\text { (MVA) }\end{array}$ & $\begin{array}{c}\text { Power } \\
\text { Loss }\end{array}$ & P.f & $V$ min & $\begin{array}{l}\text { Loss } \operatorname{Re}- \\
\text { duction } \%\end{array}$ \\
\hline \multirow[b]{2}{*}{$1 \mathrm{DG}$} & Proposed & $\begin{array}{l}\text { Bus } \\
\text { Size }\end{array}$ & & $\begin{array}{c}61 \\
2.22\end{array}$ & & 2.22 & 23.15 & 0.81 & 0.9734 & 89.71 \\
\hline & GA [29] & $\begin{array}{l}\text { Bus } \\
\text { Size }\end{array}$ & & $\begin{array}{c}61 \\
2.16\end{array}$ & & 2.16 & 38.45 & NA & NA & 82.91 \\
\hline \multirow{5}{*}{$3 \mathrm{DG}$} & Proposed & $\begin{array}{l}\text { Bus } \\
\text { Size }\end{array}$ & $\begin{array}{c}11 \\
0.616\end{array}$ & $\begin{array}{c}18 \\
0.452\end{array}$ & $\begin{array}{c}61 \\
2.050\end{array}$ & 3.119 & 4.25 & $\begin{array}{l}0.82 \\
0.81 \\
0.81\end{array}$ & $\begin{array}{c}0.9972 \\
(65)\end{array}$ & 98.11 \\
\hline & Hybrid [30] & $\begin{array}{l}\text { Bus } \\
\text { Size }\end{array}$ & $\begin{array}{c}18 \\
0.48\end{array}$ & $\begin{array}{c}61 \\
2.06\end{array}$ & $\begin{array}{c}66 \\
0.53\end{array}$ & 3.07 & 4.30 & $\begin{array}{l}0.77 \\
0.83 \\
0.82\end{array}$ & NA & 98.1 \\
\hline & CPLS [31] & $\begin{array}{l}\text { Bus } \\
\text { Size }\end{array}$ & $\begin{array}{c}21 \\
0.723\end{array}$ & $\begin{array}{c}61 \\
2.20\end{array}$ & $\begin{array}{c}64 \\
0.438\end{array}$ & 3.356 & 7.1 & $\begin{array}{l}0.81 \\
0.81 \\
0.81\end{array}$ & $\begin{array}{c}0.9934 \\
(69)\end{array}$ & 96.84 \\
\hline & EA [32] & $\begin{array}{l}\text { Bus } \\
\text { Size }\end{array}$ & $\begin{array}{c}11 \\
0.668\end{array}$ & $\begin{array}{c}18 \\
0.458\end{array}$ & $\begin{array}{c}61 \\
2.113\end{array}$ & 3.239 & 4.48 & $\begin{array}{l}0.82 \\
0.83 \\
0.82\end{array}$ & NA & NA \\
\hline & EA-OPF [32] & $\begin{array}{l}\text { Bus } \\
\text { Size }\end{array}$ & $\begin{array}{c}11 \\
0.611\end{array}$ & $\begin{array}{c}18 \\
0.456\end{array}$ & $\begin{array}{c}61 \\
2.067\end{array}$ & 3.134 & 4.27 & $\begin{array}{l}0.81 \\
0.83 \\
0.81\end{array}$ & NA & NA \\
\hline
\end{tabular}


For CI load: the power loss was reduced from $191.5 \mathrm{~kW}$ to $60.70 \mathrm{~kW}, 123.67 \mathrm{~kW}$, and $4 \mathrm{~kW}$ for DG type I, DG type II, and DG type III, respectively.

For CZ load: the best voltage profile and minimum power loss were obtained in this type of load when the three types of DGs were placed at 11,18, and 61 for the three types of loads.

\section{Conclusions}

This paper presented an efficient hybrid analytical and metaheuristic technique to find the optimal locations and sizes of different and multiple types of DGs in order to minimize active power losses and improve the overall voltage profile. The hybrid technique was applied to three types of static loads in order o check the robustness of the proposed method. A metaheuristic SSA technique was proposed in order to ascertain the optimal allocation of the DG units in the three types of loads- $\mathrm{CP}, \mathrm{CI}$, and $\mathrm{CZ}-$ while the analytical technique determined the proper sizes. The proposed algorithm was tested on 33-bus and 69-bus systems, and the results illustrated in the tables and figures proved that the power loss reduction reaches the maximum value in the case of the incorporation of three DGs of type III for the three types of loads.

Author Contributions: Conceptualization, A.A.M. and S.K.; data curation, A.S. and A.A.M.; formal analysis, S.K.; resources, A.A.M., T.K. and S.-B.R.; methodology, A.S., T.K. and S.-B.R.; software, A.A.M., S.K. and A.S.; supervision, S.K., T.K. and S.-B.R.; validation, A.S., T.K. and S.-B.R.; visualization, A.A.M., T.K. and S.-B.R.; writing—original draft, A.A.M. and A.S.; writing-review and editing, S.K., T.K. and S.-B.R. All authors together organized and refined the manuscript in the present form. All authors have approved the final version of the submitted paper. All authors have read and agreed to the published version of the manuscript.

Funding: This work was supported by "Development of Modular Green Substation and Operation Technology" of the Korea Electric Power Corporation (KEPCO).

Institutional Review Board Statement: Not applicable.

Informed Consent Statement: Not applicable.

Data Availability Statement: Not applicable.

Conflicts of Interest: The authors declare no conflict of interest.

\section{References}

1. Reddy, P.D.P.; Reddy, V.C.V.; Manohar, T.G. Whale optimization algorithm for optimal sizing of renewable resources for loss reduction in distribution systems. Renew. Wind Water Sol. 2017, 4, 1-13. [CrossRef]

2. Kazerani, M.; Tehrani, K. Grid of Hybrid AC/DC Microgrids: A New Paradigm for Smart City of Tomorrow. In Proceedings of the 2020 IEEE 15th International Conference of System of Systems Engineering (SoSE), Budapest, Hungary, 2-4 June 2020; pp. 175-180.

3. Kemikem, D.; Boudour, M.; Benabid, R.; Tehrani, K. Quantitative and Qualitative Reliability Assessment of Reparable Electrical Power Supply Systems using Fault Tree Method and Importance Factors. In Proceedings of the 2018 13th Annual Conference on System of Systems Engineering (SoSE), Paris, France, 19-22 June 2018; pp. 452-458.

4. Singh, R.K.; Goswami, S.K. Optimum allocation of distributed generations based on nodal pricing for profit, loss reduction and voltage improvement including voltage rise issue. Electr. Power Energy Syst. 2010, 32, 637-644. [CrossRef]

5. Caponetto, R.; Fortuna, L.; Fazzino, S.; Xibilia, M.G. Chaotic sequences to improve the performance evolutionary algorithms. IEEE Trans. Evol. Comput. 2003, 7, 289-304. [CrossRef]

6. Ali, E.S.; Abd Elazim, S.M.; Abdelaziz, A.Y. Optimal allocation and sizing of renewable distributed generation using ant lion optimization algorithm. Electr. Eng. 2018, 100, 99-109. [CrossRef]

7. El-Zonkoly, A. Optimal placement of multi-distributed generation units including different load models using particle swarm optimisation. IET Gener. Transm. Distrib. 2011, 5, 760-771. [CrossRef]

8. Moradi, M.; Abedini, M. A combination of genetic algorithm and particle swarm optimization for optimal DG location and sizing in distribution systems. Int. J. Electr. Power Energy Syst. 2012, 34, 66-74. [CrossRef]

9. Abu-Mouti, F.S.; El-Hawary, M.E. Optimal distributed generation allocation and sizing in distribution systems via artificial bee colony algorithm. IEEE Trans. Power Deliv. 2011, 26, 2090-2101. [CrossRef]

10. García, J.A.M.; Mena, A.J.G. Optimal distributed generation location and size using a modified teaching-learning based optimization algorithm. Int. J. Electr. Power Energy Syst. 2013, 50, 65-75. [CrossRef] 
11. Nekooei, K.; Farsangi, M.M.; Nezamabadi-Pour, H.; Lee, K.Y. An improved multi-objective harmony search for optimal placement of DGs in distribution systems. IEEE Trans. Smart Grid 2013, 4, 557-567. [CrossRef]

12. Kaur, S.; Kumbhar, G.; Sharma, J. A MINLP technique for optimal placement of multiple DG units in distribution systems. Int. J. Electr. Power Energy Syst. 2014, 63, 609-617. [CrossRef]

13. Hosseini, S.A.; Madahi, S.S.K.; Razavi, F.; Karami, M.; Ghadimi, A.A. Optimal sizing and siting distributed generation resources using a multiobjective algorithm. Turk. J. Electr. Eng. Comput. Sci. 2013, 21, 825-850.

14. Sultana, U.; Khairuddin, A.B.; Aman, M.; Mokhtar, A.; Zareen, N. A review of optimum DG placement based on minimization of power losses and voltage stability enhancement of distribution system. Renew. Sustain. Energy Rev. 2016, 63, 363-378. [CrossRef]

15. Singh, A.; Parida, S. Novel sensitivity factors for DG placement based on loss reduction and voltage improvement. Int. J. Electr. Power Energy Syst. 2016, 74, 453-456. [CrossRef]

16. Prakash, D.B.; Lakshminaraya, C. Optimal siting of capacitors in radial distribution network using whale optimization algorithm. Alex. Eng. J. 2016. [CrossRef]

17. Khodabakhshian, A.; Andishgar, M.H. Simultaneous Placement and Sizing of DGs and Shunt Capacitors in Distribution Systems by Using IMDE algorithm. Electr. Power Energy Syst. 2016, 82, 599-607. [CrossRef]

18. Haque, M.H. Load flow-solution of distribution systems with voltage dependent load models. Electr. Power Syst. Res. 1996, 36, 151-156. [CrossRef]

19. Roy, N.K.; Hossain, M.J.; Pota, H.R. Voltage profile improvement for distributed wind generation using D-STATCOM. In Proceedings of the IEEE PES General Meeting, Detroit, MI, USA, 24-28 July 2011.

20. Dahal, S.; Mithulananthan, N.; Saha, T. Investigation of small signal stability of a renewable energy based electricity distribution system. In Proceedings of the IEEE PES General Meeting, Minneapolis, MN, USA, 25-29 July 2010.

21. Mirjalili, S.; Gandomi, A.H.; Mirjalili, S.Z.; Saremi, S.; Faris, H.; Mirjalili, S.M. Salp Swarm Algorithm: A bio-inspired optimizer for engineering design problems. Adv. Eng. Softw. 2017, 114, 163-191. [CrossRef]

22. Sayed, G.I.; Khoriba, G.; Haggag, M.H. A novel chaotic salp swarm algorithm for global optimization and feature selection. Appl. Intell. 2018, 48, 3462-3481. [CrossRef]

23. El-Fergany, A.A. Extracting optimal parameters of PEM fuel cells using salp swarm optimizer. Renew. Energy 2018, 119, 641-648. [CrossRef]

24. Qais, M.H.; Hasanien, H.M.; Alghuwainem, S. Enhanced salp swarm algorithm: Application to variable speed wind generators. Eng. Appl. Artif. Intell. 2019, 80, 82-96. [CrossRef]

25. El-Fergany, A.A.; Hasanien, H.M. Salp swarm optimizer to solve optimal power flow comprising voltage stability analysis. Neural Comput. Appl. 2019, 32, 5267-5283. [CrossRef]

26. Moradi, M.H.; Abedinie, M.; Tolabi, H.B. Optimal multi-distributed generation location and capacity by genetic algorithms. In Proceedings of the 2010 Conference Proceedings IPEC, Singapore, 27-29 October 2010; pp. 614-618.

27. Hung, D.Q.; Mithulananthan, N. Multiple distributed generator placement in primary distribution networks for loss reduction. IEEE Trans. Ind. Electron. 2011, 60, 1700-1708. [CrossRef]

28. Muthukumar, K.; Jayalalitha, S. Optimal placement and sizing of distributed generators and shunt capacitors for power loss minimization in radial distribution networks using hybrid heuristic search optimization technique. Int. J. Electr. Power Energy Syst. 2016, 78, 299-319. [CrossRef]

29. Shukla, T.; Singh, S.; Srinivasarao, V.; Naik, K. Optimal sizing of distributed generation placed on radial distribution systems. Electr. Power Compon. Syst. 2010, 38, 260-274. [CrossRef]

30. Kansal, S.; Kumar, V.; Tyagi, B. Hybrid approach for optimal placement of multiple DGs of multiple types in distribution networks. Int. J. Electr. Power Energy Syst. 2016, 75, 226-235. [CrossRef]

31. Kumar, A.; Babu, P.V.; Murty, V.V.S.N. Distributed generators allocation in radial distribution systems with load growth using loss sensitivity approach. J. Inst. Eng. (India) Ser. B 2017, 98, 275-287. [CrossRef]

32. Mahmoud, K.; Yorino, N.; Ahmed, A. Optimal distributed generation allocation in distribution systems for loss minimization. IEEE Trans. Power Syst. 2015, 31, 960-969. [CrossRef] 